UNIVERSIDADE DE SÃO PAULO

USP

MARCOS CÉSAR AMADOR ALVES

\title{
CONTEÚDO JURÍDICO DA CLÁUSULA TRABALHISTA NOS CONTRATOS PÚBLICOS E A AFIRMAÇÃO DOS DIREITOS FUNDAMENTAIS NO TRABALHO
}

DOUTORADO EM DIREITO

ORIENTADOR: PROFESSOR ASSOCIADO OTAVIO PINTO E SILVA

FACULDADE DE DIREITO

SÃO PAULO

2014 


\section{RESUMO}

O princípio da dignidade humana necessita, como em nenhum outro momento, sair do plano etéreo. Direitos meramente de papel em nada contribuem para o verdadeiro avanço civilizacional por todos ambicionado. Para que a humanidade caminhe celeremente para a realização dos valores sedimentados ao longo de um lento processo de consciência política e jurídica que resultou na construção dos catálogos de direitos fundamentais, impreterível se mostra a efetivação plena dos direitos humanos. A convicção da imprescindibilidade da proteção da dignidade humana necessita ser materializada. A questão da efetividade dos direitos fundamentais afeta, com notável magnitude, a proteção jurídica dos trabalhadores. A Declaração de Princípios e Direitos Fundamentais no Trabalho da OIT e os postulados do trabalho decente, saudável e seguro, os quais configuram a definição dos padrões mínimos de direitos trabalhistas no âmbito internacional, não têm sido cumpridos nos diferentes países, comprometendo gravemente a tutela deferida à dignidade do trabalhador. É preciso assegurar a aplicabilidade e a realização dos direitos trabalhistas fundamentais, combatendo os abjetos casos de trabalho em condições análogas à de escravo, de discriminação de trabalhadores, de cerceamento às liberdades sindicais e negociais, de trabalho infantil, inseguro ou em condições indignas, entre inúmeras outras injustas e execráveis situações vivenciadas no ambiente laboral. No cenário econômico globalizado, em que sobressai o capitalismo financeiro, os governos necessitam assumir, como em nenhum outro momento, seu necessário papel na proteção efetiva dos direitos humanos no trabalho. Neste sentido, diante da vinculação à supremacia e à indisponibilidade dos direitos fundamentais como preceptivos essenciais da atividade administrativa no Estado Democrático de Direito, o Poder Público deve exercer sua função de induzir e modelar as condutas sociais. $O$ trabalho acadêmico presente preconiza e defende que os governos devem exercer um papel verdadeiramente ativo, a fomentar e a exigir o efetivo cumprimento dos direitos fundamentais no trabalho, notadamente pela aplicação de instrumentos jurídicos como a cláusula trabalhista nos contratos públicos. A cláusula trabalhista expressa e proclama a emanação da força cogente, vinculante, dos contratos públicos, das disposições contratuais, e revela a capacidade de subtrair os direitos subjetivos do plano abstrato, formando uma conexão real e obrigatória, alicerçada em obrigações particularizadas, diretamente imponíveis, destinadas à realização dos direitos fundamentais no trabalho e da proteção da dignidade do trabalhador, incorrendo o infrator de seus comandos, na imediata aplicação de sanções. Por conseguinte, produz implicações jurídicas materiais para a proteção do trabalho. Os contornos da concepção contemporânea do contrato público socialmente responsável demandam a adoção da cláusula laboral para a afirmação dos direitos fundamentais no trabalho. As características e particularidades do novo regime jurídico em que se inserem os contratos administrativos exprimem e legitimam a plena pertinência e juridicidade da adoção da cláusula social trabalhista em seu núcleo. Neste contexto, a realização dos padrões internacionais de proteção ao trabalhador é condição mandatória para o desenvolvimento sustentável. A contratação pública socialmente responsável que valoriza e concretiza a proteção da dignidade do trabalhador pode, verdadeiramente, influenciar as atividades econômicas, promovendo a justiça social nas relações de trabalho que encerram ao exigir, com ênfase, a formatação de padrões de emprego e ocupação laboral que respeitam os direitos humanos no trabalho.

Palavras-chave: Direito do Trabalho. Direitos fundamentais no trabalho. Desenvolvimento sustentável. Contrato público socialmente responsável. Licitação sustentável. Compra social. Efetividade das declarações de direitos sociais. Cláusula trabalhista nos contratos públicos.

Título: Conteúdo jurídico da cláusula trabalhista nos contratos públicos e a afirmação dos direitos fundamentais no trabalho. 


\begin{abstract}
The principle of human dignity, as never before, has to be pulled out of its ethereal plane. Empty rights do not contribute to the true civilization progress coveted by all. So that mankind walks faster towards the achievement of the values settled along the slow process of political and legal awareness that resulted in the construction of catalogs of fundamental rights, the full effectiveness of legal rights shall not be avoided. The indispensable protection to human dignity must be enforced with conviction. The issue of the effectiveness of fundamental principles significantly affects workers' legal protection. The ILO Declaration on Fundamental Principles and Rights at Work and the guidelines on decent, healthy and safe work, which define minimum international labour standards, have not been complied with in different countries, severely compromising the protection to workers' dignity. The applicability and enforcement of fundamental labour rights must be guaranteed to fight contemptible cases of slavery-like work conditions, workers' discrimination, retrenchment to free labour union and collective bargaining, child labour, unsafe work or under degrading conditions, among several other unfair and infamous situations experienced in the work environment. In a globalized economic scenario, where financial capitalism is emphasized, governments have to assume, as never before, their role in the effective protection of human rights at work. Accordingly, in view of the supremacy and inalienability of fundamental rights as essential principles of administrative activities of the Rule of Law, the role of the Government is to induce and shape social conducts. The present academic paper argues and claims that governments should have a decisively active role, fomenting and enforcing the effective compliance with fundamental rights at work, notably by applying legal instruments as the labour clause in public contracts. The labour clause expresses and affirms the cogent and binding force that arises out of public contracts and contractual provisions, and pulls subjective rights out of their abstract plane, establishing an actual and mandatory connection grounded on specific obligations immediately enforceable and aimed to realize fundamental rights at work and protect the dignity of workers, and applying immediate sanctions on the offender of such legal provisions. Therefore, it produces real and concrete legal developments to labour protection. The outlines of the contemporary conception of socially responsible public contracts require the adoption of the labour clause for the enforcement of fundamental labour rights at work. The characteristics and specificities of the new legal regime, which comprises administrative contracts, express and legitimize the full pertinence and legality of including the labour clause among their provisions. In this context, the compliance with international workers' protection standards is mandatory to a sustainable development. Socially responsible public contracts that value and enforce the protection to workers' dignity may effectively influence economic activities, promoting social justice in labour relations that emphatically claim for the structuring of employment and labour standards that respect human rights at work.
\end{abstract}

Keywords: Labour Law. Fundamental rights at work. Sustainable development. Socially responsible public contract. Sustainable public procurement. Social public procurement. Effectiveness of social rights declarations. Labour clause in public contracts.

Title: Labour clause in public contracts and the affirmation of the fundamental rights at work. 


\section{RIASSUNTO}

Il principio della dignità umana ha bisogno, come in nussun altro momento, di uscire da un piano astratto. I diritti che restano semplicemente sulla carta non contribuiscono al processo di civilizzazione ambito da tutti. Affinchè l'umanità cammini velocemente verso la realizzazione dei valori sedimentatisi nel corso di un lento processo di coscienza politica e giuridica che si è concretizzato nella stesura dei cataloghi sui diritti fondamentali, si mostra inevitabile la piena efficacia dei diritti umani. La convinzione dell'imprescendibilità della protezione della dignità umana ha bisogno di essere messa in pratica. La questione dell'efficacia dei diritti fondamentali colpisce, con notevole impatto, la protezione giuridica dei lavoratori. La Dichiarazione dei Principi e dei Diritti Fondamentali del Lavoro dell'OIL e i postulati per un lavoro degno, sano e sicuro, che configurano una definizione delle norme minime dei diritti dei lavoratori in ambito internazionale, non sono stati adempiti nei diversi paesi, compromettendo gravemente la protezione riconosciuta alla dignità del lavoratore. È necessario assicurare l'applicabilità e la realizzazione dei diritti fondamentali dei lavoratori, combattendo gli abietti casi di lavoro in condizioni simili a quelle di uno schiavo, di riduzione delle libertà sindacali e di trattativa, di lavoro infantile, insicuro o in condizioni indegne, tra le altre numerose ingiuste e esecrabili situazioni vissute nell'ambiente lavorativo. In uno scenario economico globalizzato, nel quale eccelle il capitalismo finanziario, i governi devono assumere, come in nessun altro momento, il loro indispensabile ruolo nella protezione effettiva dei diritti umani nel lavoro. In questo senso, considerando il legame con la supremazia e con l'indisponibilità dei diritti fondamentali come precetti essenziali dell'attività amministrativa in uno Stato Democratico di Diritto, il Potere Pubblico deve esercitare la propria funzione per indurre e modellare le condotte sociali. Il presente lavoro accademico difende e sostiene che i governi debbano esercitare un ruolo realmente attivo nel promuovere e nell'esigere l'effettivo adempimento dei diritti fondamentali del lavoro, in particolare nell'applicazione di strumenti giuridici come la clausola del lavoro nei contratti pubblici. La clausola dei lavoratori esprime e proclama l'emanazione di forza cogente vincolante, dei contratti pubblici, delle disposizioni contrattuali, e rivela la capacità di sottrarre i diritti soggettivi dal piano astratto, formando una connessione reale e obbligatoria, articolata in obblighi particolareggiati, imponibili direttamente, rivolti alla realizzazione dei diritti fondamentali del lavoro ed alla protezione della dignità del lavoratore, facendo incorrere colui che viola queste regole, nell'immediata applicazione di sansioni. Di conseguenza, produce implicazioni giuridiche materiali per la protezione del lavoro. I contorni della concezione contemporanea del contratto pubblico socialmente responsabile richiedono l'adozione della clausola del lavoro per l'affermazione dei diritti fondamentali del lavoro. Le caratteristiche e le particolarità del nuovo quadro giuridico in cui operano i contratti amministrativi esprimono e legittimano la piena rilevanza e legittimità dell'adozione della clausola sociale del lavoro nel suo nucleo. In questo contesto, il raggiungimento degli standard internazionali di tutela del lavoratore è una condizione obbligatoria per uno sviluppo sostenibile. La contrattazione socialmente responsabile che valorizza e implementa la tutela della dignità del lavoratore può, realmente,influenzare le attività economiche, promuovendo la giustizia sociale nei rapporti di lavoro che racchiudono la domanda, con particolare attenzione, alla formattazione di modelli d'impiego e occupazionali che rispettino i diritti umani sul posto di lavoro.

Parole-chiavi: Diritto del Lavoro. Diritti fondamentali del Lavoro. Sviluppo Sostenibile. Contratto pubblico socialmente responsabile. Offerta sostenibile. Compra sociale. Efficacia delle dichiarazioni sociali. Clausola di lavoro nei contratti pubblici.

Titolo: Contenuto giuridico della clausola del lavoro nei contratti pubblici e affermazione dei diritti fondamentali sul lavoro. 


\section{INTRODUÇÃO}

\section{Tema a ser desenvolvido e suas limitações}

A pesquisa realizada versa, como tema central, sobre o "conteúdo jurídico da cláusula trabalhista nos contratos públicos e a afirmação dos direitos fundamentais no trabalho".

O trabalho produzido insere-se, em relação à linha de pesquisa "Direitos Sociais no contexto dos Direitos Humanos", no projeto "A eficácia dos institutos, normas e princípios de direito interno, comunitário e internacional do trabalho e a efetivação dos Direitos Humanos" do Programa de Pós-Graduação em Direito desenvolvido pelo Departamento de Direito do Trabalho e da Previdência Social da Faculdade de Direito da Universidade de São Paulo.

A singular importância da compreensão do instituto ${ }^{2}$ da cláusula trabalhista nos contratos públicos como instrumento destinado à realização e concretização dos direitos fundamentais no trabalho é aclarada e repercutida enquanto temática indispensável à afirmação da proteção da dignidade do trabalhador, conquista inalienável da pessoa e anseio de toda a comunidade internacional. Evidencia-se não apenas a importância da dimensão social da contratação pública no enfrentamento do trabalho indigno, como também o papel essencial de um modelo efetivo de desenvolvimento e de sustentabilidade social o qual exija a adoção progressiva dos direitos fundamentais no trabalho.

A cláusula trabalhista nos contratos públicos, ao enaltecer o respeito aos direitos fundamentais no trabalho, fora de dúvida, torna-se instrumento jurídico precioso e poderoso para a concretização da proteção da dignidade do trabalhador.

De se destacar que, embora tenha sido previsto no âmbito das normas internacionais pela Convenção $n^{\circ}$ 94, da OIT, adotada em 1949, o instituto da cláusula trabalhista nos contratos públicos, o qual preconiza, em seus postulados, o respeito pelas normas fundamentais de proteção ao trabalho humano na execução de contratos públicos, tem sido largamente incompreendido. A pesquisa proposta versa sobre tal questão e

${ }^{2}$ Segundo De Plácido e Silva: "Instituto, na terminologia jurídica, é a expressão usada para designar o conjunto de regras e princípios jurídicos que regem certas entidades ou certas situações de direito." (In: SILVA, De Plácido e. Vocabulário Jurídico. 29. ed. Rio de Janeiro: Forense, 2012, p. 754). 
propugna, em seu desenvolvimento, a relação concludente do conteúdo jurídico da cláusula trabalhista nos contratos públicos com a afirmação dos direitos fundamentais no trabalho.

Os direitos de proteção ao trabalho constituem um sistema ético e legal, baseado no ideal da justiça social. A contratação pública orientada para a afirmação dos direitos fundamentais no trabalho, neste diapasão, deve ser promovida, exigida e fortalecida. A cláusula trabalhista nos contratos públicos representa a materialização de mencionado escopo.

O desenvolvimento da abordagem do objeto principal do presente estudo é permeado pela análise de temas secundários, os quais se complementam e se interrelacionam permanentemente, a saber: (I) a dimensão social da contratação pública; (II) os direitos fundamentais no trabalho; (III) a cláusula trabalhista nos contratos públicos como instituto jurídico e novo paradigma; (IV) os aspectos específicos da cláusula trabalhista nos contratos públicos nos modelos europeu e brasileiro; e (V) a cláusula trabalhista nos contratos públicos como instrumento de afirmação dos direitos fundamentais do trabalho e sua determinante implicação para o desenvolvimento sustentável.

O âmbito do estudo proposto compreende a determinação inicial dos aspectos principais que caracterizam o fenômeno da dimensão social da contratação pública e sua relação com o Direito. São observados, destarte, os impactos do sistema de contratação no setor público. Exterioridades da teoria dos direitos fundamentais e da vinculação do Poder Público à efetivação e concretização dos direitos fundamentais no trabalho são abordadas e discutidas. A análise detida dos contratos públicos é, nessa altura, efetivada, alcançando seus aspectos gerais, conceito e elementos essenciais, requisitos de validade, bem como os princípios especiais aplicáveis. Em seguida, em tipologia, são apresentadas as principais modalidades de contratação aplicáveis na seara pública. Forma, conteúdo e cláusulas essenciais dos contratos públicos são ressaltados, assim como seus elementos e características centrais.

Os contornos da concepção contemporânea do contrato público socialmente responsável são apresentados, destacando, em mencionado contexto, os aspectos premonitórios da afirmação dos direitos fundamentais no trabalho por meio dos contratos públicos. Nesse passo, evidencia as características e particularidades dos contratos administrativos e a plena pertinência e juridicidade da adoção da cláusula social trabalhista em seu núcleo. 
Em seguida, a pesquisa abrange a determinação dos direitos fundamentais no trabalho no plano internacional, compreendendo a análise dos desafios à proteção do trabalho humano diante da complexidade do mundo contemporâneo. Nesse compasso, é considerada e examinada, como conteúdo principal, a Declaração da Organização Internacional do Trabalho sobre os Princípios e Direitos Fundamentais no Trabalho, além das dimensões específicas de proteção do trabalho decente e do trabalho seguro, em consonância com os postulados da OIT.

No que respeita à Declaração de Princípios e Direitos Fundamentais no Trabalho da OIT, são pontuadas as liberdades de associação e de organização sindical e ao reconhecimento efetivo do direito de negociação coletiva, a eliminação de todas as formas de trabalho forçado ou obrigatório, a abolição efetiva do trabalho infantil e a eliminação da discriminação em matéria de emprego e ocupação. Quanto ao direito ao trabalho decente, são exibidos os postulados da OIT que definem o trabalho produtivo e em condições laborais justas, com a correspondente proteção e aplicação dos princípios e direitos fundamentais no trabalho e normas internacionais do trabalho, a geração de oportunidades de trabalho emprego e renda, o diálogo social e equidade para o desenvolvimento e a proteção social dos trabalhadores, encerrando-se com os preceitos de afirmação do trabalho seguro e saudável.

Os desafios da implementação dos direitos fundamentais no trabalho e da concretização dos direitos sociais são enfrentados nesse momento. No mesmo campo, são abordados diferentes entendimentos acerca da densidade normativa dos direitos fundamentais no trabalho. A realização dos direitos fundamentais no trabalho a partir do sistema normativo da OIT é, pois, ressaltada. Nesse particular, são caracterizados os mecanismos de aplicação e controle das normas internacionais do trabalho. Sobretudo, demonstra-se a real necessidade da existência de instrumentos que viabilizem os meios de promover intervenção afirmativa destinada à concretização e efetivação dos direitos fundamentais no trabalho.

A partir da definição do objeto de proteção estabelecido, a pesquisa avança em direção à compreensão dos aspectos específicos da interseção existente entre os direitos fundamentais no trabalho e o conteúdo jurídico da Convenção no 94 da OIT, a qual preconiza a adoção da cláusula trabalhista nos contratos firmados por autoridades públicas.

É, então, introduzido o instituto da cláusula trabalhista nos contratos públicos e sua relação com a afirmação dos direitos fundamentais no trabalho. 
A especial transcendência ensejada pela adoção da cláusula trabalhista nos contratos públicos, preconizada pela Convenção n ${ }^{\circ}$ 94, da OIT, é examinada e estudada em profundidade, bem como a repercussão dos efeitos que provoca para a concretização dos direitos fundamentais no trabalho. O instituto especificado percebe detida análise, envolvendo sua conceituação, fundamentação e aplicação. É lavrada a análise crítica da Convenção $n^{\circ}$ 94, da OIT, propondo-se a atualização contextual de suas disposições, em consonância com os novos desafios enfrentados por força das profundas transformações que atingem as relações de trabalho, as quais evidenciam progressiva complexidade e mutação constante, em contínuo processo de adaptação às exigências econômicas hodiernas.

A pesquisa avança para alcançar o ponto nevrálgico do estudo proposto, a saber, os efeitos da conjugação da dimensão social da contratação pública com o conteúdo jurídico das declarações de direitos humanos no trabalho enquanto conspícuo arcabouço para a construção e efetivação de novo paradigma orientado para a afirmação dos direitos fundamentais trabalhistas. Nessa seção, são apresentadas as relações existentes entre a imposição e execução da cláusula trabalhista nos contratos públicos e a materialização dos direitos fundamentais no trabalho.

Com ênfase especial, o trabalho se concentra na análise dos aspectos específicos de modelos de cláusulas sociais nos contratos públicos propostos internacionalmente, notadamente no direito europeu e brasileiro, no alvitre de realizar a concretização dos direitos fundamentais no trabalho.

No tocante ao direito europeu, são observados os critérios sociais de adjudicação nos contratos públicos e analisadas fontes de direito comunitárias, como as Diretivas 2004/18/CE e 2004/17/CE. No que se refere ao direito brasileiro, o estudo observa a aptidão da contratação pública como instrumento de promoção do desenvolvimento nacional sustentável, com a apreciação dos dispositivos constitucionais aplicáveis, do conteúdo jurídico da lei federal $n^{\circ} 8.666 / 1993$, a partir das alterações promovidas pela lei federal $n^{\text {o }}$ 12.349/2010, além de outras leis correlatas, instruções normativas e outros instrumentos pertinentes. A atuação do Ministério Público do Trabalho, dos Tribunais de Contas e dos sindicatos em relação à temática é destacada nesse ponto. São, então, ressaltadas as insuficiências do modelo brasileiro.

O estudo discute, ademais, a essencialidade da promoção de um modelo efetivo de desenvolvimento e de sustentabilidade econômica e social o qual exija a adoção 
progressiva dos direitos laborais, com a materialização da proteção da dignidade do trabalhador, enaltecendo a cláusula trabalhista nos contratos públicos como instrumento verdadeiro de afirmação dos direitos fundamentais do trabalho. São expostas, em associação, as temáticas da função do direito para a transformação da sociedade e para a afirmação do sistema de valores vigentes e do enfrentamento da crise da proteção ao trabalho por meio da reafirmação da vertente dos direitos humanos e da dimensão social dos contratos públicos. Desse modo, a concretização dos direitos fundamentais no trabalho é apresentada como condição primeira no sistema de contratação pública focada no valor social do trabalho e na proteção da dignidade do trabalhador como princípios éticos de humanização das relações de trabalho.

Ressalta-se, nesse sentido, a correlação existente entre cláusula trabalhista nos contratos públicos e justiça social, exibindo-se os aspectos da dimensão social da contratação pública e da necessária harmonização da sustentabilidade social e econômica.

A conclusão do estudo se volta à apresentação das constatações, evidências e proposições estabelecidas a partir da pesquisa levada a efeito, versando, por fim, sobre questões relacionadas ao enfrentamento do processo de desvalorização do trabalho humano no contexto da globalização econômica, ressaltando os efeitos específicos da relação concludente existente entre a afirmação dos direitos fundamentais, a destinação dos recursos públicos e o desenvolvimento social sustentável.

O instituto da cláusula de trabalhista nos contratos públicos corresponde à melhoria da vida das pessoas no exercício laboral, no qual direitos fundamentais dos trabalhadores necessitam ser respeitados, concretizados. Todo trabalhador tem direito ao trabalho, respeitando-se sua dignidade e seus direitos fundamentais declarados.

\section{Justificativa da escolha e da importância do tema}

A vocação contemporânea da ciência jurídica está centrada, como em nenhum outro momento histórico, na proteção da pessoa. André Franco Montoro ${ }^{3}$, em enunciado direcionamento, salienta que "talvez em nenhuma época, como hoje, o estudo e a prática do Direito tenham se identificado tanto com a própria defesa da civilização e dos valores

\footnotetext{
${ }^{3}$ MONTORO, André Franco. Introdução à ciência do direito. 20. ed. São Paulo: Revista dos Tribunais, 1991, p. 03.
} 
humanos".

A consagração da dignidade humana no constitucionalismo moderno enquanto valor central da sociedade corresponde a um dos mais notáveis avanços jurídicos percebidos. É possível afirmar, a título propedêutico, que raras ideias se tornaram tão essenciais na cultura ocidental quanto a convicção da imprescindibilidade da proteção da dignidade humana. O processo de construção dos direitos humanos é a expressão maior do quanto aludido. $\mathrm{O}$ direito internacional e os sistemas constitucionais das democracias mais avançadas alçaram o princípio da dignidade humana à posição suprema do ordenamento jurídico.

A Declaração Universal dos Direitos Humanos, instrumento internacional máximo de afirmação da prevalência da pessoa humana, em seu preâmbulo, prevê: " $O$ reconhecimento da dignidade inerente a todos os membros da família humana e dos seus direitos iguais e inalienáveis constitui o fundamento da liberdade, da justiça e da paz no mundo". 4

A Constituição Brasileira, promulgada em 1988, ao definir seus princípios fundamentais, estabelece no artigo $1^{\circ}$, inciso III:

Artigo $1^{\circ}$ - A República Federativa do Brasil, formada pela união indissolúvel dos Estados e Municípios e do Distrito Federal, constitui-se em Estado Democrático de Direito e tem como fundamentos:

III - a dignidade da pessoa humana;

Para, Ingo Wolfgang Sarlet ${ }^{5}$, a dignidade humana é:

a qualidade intrínseca e distintiva reconhecida em cada ser humano que o faz merecedor do mesmo respeito e consideração por parte do Estado e da comunidade, implicando, neste sentido, um complexo de direitos e deveres fundamentais que assegurem a pessoa tanto contra todo e qualquer ato de cunho degradante e desumano, como venham a lhe garantir as condições existenciais mínimas para uma vida saudável, além de propiciar e promover sua participação ativa e co-responsável nos destinos da própria existência e da vida em comunhão com os demais seres humanos.

\footnotetext{
${ }^{4}$ Grifo nosso.

${ }^{5}$ SARLET, Ingo Wolfgang. Dignidade da pessoa humana e direitos fundamentais. 6. ed. Porto Alegre: Livraria do Advogado, 2008, p. 63.
} 
A dignidade humana apresenta-se, doravante, enquanto princípio fundamental, o qual se irradia para todos os quadrantes do ordenamento jurídico. De modo ainda mais pungente, repercute seus notáveis efeitos na seara do Direito do Trabalho.

O trabalho, fora de dúvida, é o meio fundamental dado à pessoa para efetivar e sublimar sua existência com dignidade. Sua proteção, em decorrência, assume diferenciado relevo e notória importância.

Em 18 de junho de 1998, cinquenta anos, portanto, após o advento da Declaração Universal dos Direitos Humanos da Organização das Nações Unidas, foi adotada, pela Organização Internacional do Trabalho, a Declaração sobre os Princípios e Direitos Fundamentais no Trabalho. Trata-se do instrumento internacional que define os direitos fundamentais sociais relativos ao trabalho, que constituem concretizações da dignidade humana. Na mesma direção, a proteção das dimensões do trabalho decente e do trabalho seguro, propostas pela OIT.

Ocorre que as declarações de direitos não têm sido suficientes para a realização e materialização da proteção da dignidade humana. No campo das relações de trabalho, enunciada realidade se faz sentir com intensidade ainda maior.

O consagrado jurista italiano Norberto Bobbio $^{6}$, pontifica: "O problema fundamental em relação aos direitos do homem, hoje, não é tanto o de justificá-los, mas o de protegê-los". 7

Para Jorge Luiz Souto Maior ${ }^{8}:$ "a mera declaração de um direito não equivale à transposição do valor que lhe integra para a realidade social".

Segundo preleciona Otavio Pinto e Silva 9 : "A realidade demonstra que a simples inserção de um grande número de direitos trabalhistas na Constituição ou na lei não basta, por si só, para garantir a tutela dos trabalhadores".

Nesse contexto, posiciona-se o tema central do estudo proposto, o qual versa sobre o "conteúdo jurídico da cláusula trabalhista nos contratos públicos e a afirmação dos

\footnotetext{
${ }^{6}$ BOBBIO, Norberto. A era dos direitos. Rio de Janeiro: Campus, 1992, p. 24.

${ }^{7}$ Grifo nosso.

${ }^{8}$ MAIOR, Jorge Luiz Souto. O Direito Social transcende os Direitos Humanos. In: NALINI, José Renato; CARLINI, Angélica. Direitos Humanos e formação jurídica. Rio de Janeiro: Forense, 2010, p. 253.

${ }^{9}$ SILVA, Otavio Pinto e. A função do Direito do Trabalho no mundo atual. In: CORREIA, Marcus Orione Gonçalves. (Org.). Curso de Direito do Trabalho - Teoria Geral do Direito do Trabalho. V. I. São Paulo: Editora LTr, 2007, p. 143.
} 
direitos fundamentais no trabalho". Somente se concretizados, os direitos fundamentais no trabalho serão instrumentos efetivos para a afirmação da dignidade do trabalhador, conquista inalienável da pessoa humana e anseio de toda a comunidade internacional. A investigação da dimensão social da contratação pública insere-se, precisamente, no cerne da mencionada questão.

Ao jurista, mais do que analisar o texto normativo e sua estrutura formal, apresenta-se o desafio de encontrar os meios de efetivação das declarações de direitos para a implementação de uma sociedade justa. Mais do que a abordagem ou a análise dogmática meramente positivista, importa uma visão funcional do Direito. O papel do Direito de instrumento de transformação da sociedade e de concretização do sistema de valores almejados necessita, como em nenhum outro momento, ser prontamente exercido.

Nesse sentido, o conteúdo do Direito do Trabalho não se esgota no estudo da legislação trabalhista. O Direito não se reduz à normatividade. Ele vai muito além, na busca incessante pela Justiça. Daí seu notável fascínio. Envolve, fora de dúvida, as peculiaridades de um autêntico e sensível fenômeno.

As relações de trabalho evidenciam progressiva complexidade e mutação constante, em contínuo processo de adaptação às exigências modernas. Diante das profundas transformações produzidas pela globalização, pela evolução tecnológica e pelas novas condições de competição da economia mundial, a adoção de medidas efetivas para a concretização dos direitos fundamentais no trabalho revela-se premente e imprescindível.

Notadamente, os fenômenos da globalização e da integração econômica, assim como o novo padrão de concorrência internacional, têm produzido efeitos intensos e transformações sensíveis na proteção do trabalho. As práticas que decorrem do descumprimento de normas mínimas de trabalho constituem vantagens comerciais ilegítimas e implicam o processo de desvalorização da força humana de trabalho. Nesse sentido, urge que os direitos trabalhistas passem a ser vistos sob uma perspectiva transnacional, com real capacidade de concretização e afirmação frente a interesses meramente econômicos, os quais, na atualidade, têm prevalecido, em nítido prejuízo aos preceptivos de justiça social e dos direitos fundamentais.

Arnaldo Süssekind ${ }^{10}$ aduz:

\footnotetext{
${ }^{10}$ SÜSSEKIND, Arnaldo (ca). Instituições de Direito do Trabalho. 21. ed. São Paulo: LTr, 2003, p. 1498.
} 
Reconhecendo, embora, a importância dos aspectos econômicos que fundamentam o Direito Internacional do Trabalho, afigura-se-nos, todavia, que seu principal esteio é de caráter social e concerne à universalização dos princípios da Justiça Social e da dignificação do trabalhador. É certo que razões de ordem econômica constituíam sério obstáculo à consecução desses ideais; mas são exatamente esses ideais que configuram a finalidade preponderante do direito universal do trabalho. ${ }^{11}$

É fundamental que instrumentos jurídicos sejam efetivados de modo a compelir os países a respeitar o conjunto de normas fundamentais no trabalho.

Fora de dúvida, se faz premente retirar a Declaração sobre os Princípios e Direitos Fundamentais no Trabalho e os postulados do trabalho decente e seguro do plano contemplativo, etéreo, assegurando, verdadeiramente, sua concretização. Tal, por certo, permitirá a intensificação da difusão de seus valiosos mandamentos, contribuindo para o fortalecimento das normas internacionais no contexto da globalização econômica.

Nesse sentido, o instituto da cláusula trabalhista nos contratos públicos, o qual preconiza, em seus postulados, o respeito pelas normas fundamentais de proteção ao trabalho humano na execução de contratos firmados por autoridades públicas, necessita ser largamente compreendido.

A adoção da cláusula trabalhista nos contratos públicos, inicialmente propugnada pela Convenção $\mathrm{n}^{\circ} 94$ da OIT enquanto norma internacional, estava a demandar pesquisa em profundidade, com a necessária compreensão da repercussão dos efeitos que provoca para a concretização dos direitos fundamentais no trabalho.

É de indispensável importância a sistematização e a ampliação significativa do estudo científico acerca da relação concludente entre o conteúdo jurídico da cláusula trabalhista nos contratos públicos e a realização dos direitos fundamentais no trabalho. Ademais, revela-se imprescindível a análise circunstanciada da real necessidade da existência de instrumento que viabilize os meios de promover intervenção afirmativa destinada à concretização e efetivação dos direitos fundamentais dos trabalhadores.

O estudo do instituto da cláusula trabalhista nos contratos públicos e sua relação com a afirmação dos direitos fundamentais no trabalho possibilita, assim, a exploração da dimensão social das contratações do setor público, evidenciando as características e

\footnotetext{
${ }^{11}$ Grifo nosso.
} 
particularidades das pactuações públicas e a plena pertinência da adoção de dispositivo trabalhista específico em seu núcleo.

A autêntica dimensão social da contratação pública, o contrato público socialmente responsável, o qual se situa no foco do estudo ora apresentado, prestigia, com ênfase, a formatação de padrões de emprego e ocupação laboral que respeitam os direitos humanos no trabalho. Ao mesmo tempo, a identificação do papel do Poder Público como agente fundamental de transformação, de desenvolvimento e de promoção da justiça nas relações trabalhistas, coaduna-se, plenamente, com a afirmação da proteção jurídica de direitos fundamentais e do desenvolvimento sustentável. Trata-se de arcabouço necessário para propiciar e orientar a reconciliação entre desenvolvimento econômico e justiça social.

Nesse sentido, a interseção entre a contratação pública e a afirmação dos direitos fundamentais no trabalho. No desenvolvimento da pesquisa analisa-se, minuciosamente, o referido entrelaçamento, no alvitre de se evidenciar em que medida relatada simbiose contribui para o enfrentamento do desafio de se encontrarem os meios de efetivação das declarações de direitos, no que se refere aos padrões essenciais no trabalho estabelecidos no plano internacional.

A causa precípua da construção jurídica contemporânea volta-se à proteção da dignidade humana. No campo do trabalho, esta realidade mostra-se ainda mais compassiva. Sem a afirmação e a proteção dos direitos fundamentais no trabalho, aparentemente, nenhum outro direito ou preceptivo de tutela ao trabalho subsistirá. Trata-se, fora de dúvida, da consagração de um direito social fundamental, profundamente inserido no contexto dos direitos humanos, indispensável para assegurar sua realização.

Incumbe ao Direito descerrar caminhos para o pleno desenvolvimento do indivíduo em todas as suas dimensões. Garantir o respeito os direitos fundamentais no trabalho, prevenindo os danos aos valiosos bens jurídicos tutelados, corresponde a prover o próprio equilíbrio social e a equidade. Para tanto, a necessidade de avançar na pesquisa e no conhecimento científico dos instrumentos destinados à concretização dos direitos fundamentais no trabalho, seu conteúdo, suas verdadeiras dimensões, as ameaças e consequências que emergem de sua ineficácia. É, pois, inegável a relevância da compreensão plena do conteúdo jurídico da cláusula trabalhista nos contratos públicos e o estudo dos aspectos científicos pertinentes. 
Todas as nações, elidindo o indesejável e inaceitável retrocesso social, devem almejar a evolução plena na direção dos mais altos padrões de direitos humanos e trabalhistas, reconhecendo, efetivamente, a importância dos institutos jurídicos destinados a realizar tão relevantes desígnios.

\section{Principais questões a serem analisadas}

O estudo científico do tema “conteúdo jurídico da cláusula trabalhista nos contratos públicos e a afirmação dos direitos fundamentais no trabalho" demanda especial denodo no que tange à eleição das principais questões a serem analisadas. O próprio aperfeiçoamento do trabalho de investigação coopta, à concepção inicial, novas luzes as quais refletem, inelutavelmente, a incorporação de diferentes indagações e renovados contornos à pesquisa.

A tese doutoral apresenta, como conteúdo central, a proposta de adoção material da cláusula trabalhista nos contratos públicos como instrumento efetivo de afirmação dos direitos fundamentais no trabalho. A proposição defendida se debruça, precisamente, sobre enunciada questão. Em essência, a tese apresentada relaciona-se à análise de temas jurídicos como:

$\checkmark$ a necessidade de concretização dos direitos fundamentais no trabalho e a contribuição determinante do instituto da cláusula trabalhista nos contratos públicos;

$\checkmark$ a repulsa do direito às contratações públicas ou ao uso de recursos públicos que financiem violações a direitos fundamentais no trabalho;

$\checkmark$ as relações existentes entre contratação pública e a vinculação aos direitos fundamentais;

$\checkmark$ a supremacia e a indisponibilidade dos direitos fundamentais como preceptivos essenciais da atividade administrativa no Estado Democrático de Direito;

$\checkmark$ a reprovação ético-jurídica do nominado "custo do trabalho" como fator de diferenciação competitiva em licitações e contratações públicas;

$\checkmark$ a juridicidade da adoção da cláusula trabalhista nos contratos públicos; 
$\checkmark$ a afirmação dos direitos fundamentais no trabalho como condição essencial da contratação pública;

$\checkmark$ reflexões sobre a função interventiva do Estado no sentido de promover, induzir e modelar o comportamento do setor privado, valorizando as organizações que respeitam os direitos fundamentais no trabalho, inviabilizando aquelas que se utilizam de trabalho análogo ao de escravo, trabalho infantil, enfim, que desrespeitam a dignidade do trabalhador;

$\checkmark$ a adoção da cláusula trabalhista nos contratos públicos como política pública orientada à afirmação dos direitos fundamentais no trabalho;

$\checkmark$ o compromisso dos diferentes países, especialmente do Brasil, com a afirmação dos direitos fundamentais no trabalho, notadamente por meio da adoção a cláusula trabalhista nos contratos públicos como efetiva política pública

O desenvolvimento da pesquisa se concentra na análise aprofundada da importância do estudo da afirmação dos direitos fundamentais no trabalho ressaltando que, ao jurista, mais do que analisar a norma e sua estrutura formal sob a perspectiva dogmática positivista, apresenta-se o desafio de encontrar os meios funcionais de efetivação das declarações de direitos para a implementação de uma sociedade justa. Ao Direito, como ciência de organização social, incumbe a função de materialização e concretização do sistema de valores almejados pela sociedade. Ressalta-se, outrossim, o posicionamento das questões lançadas diante do permanente desafio da sustentabilidade social e econômica. Nesse passo, é contextualizado o instituto da cláusula trabalhista nos contratos públicos e introduzido o seu jurídico conteúdo.

Para o embasamento do tema principal tratado, questões secundárias são enfrentadas. É possível afirmar que o trabalho gravita, de modo conexo, em torno dos pontos seguintes:

$\checkmark$ repercussões da dimensão social da contratação pública em relação ao avanço da proteção dos direitos fundamentais no trabalho no sistema capitalista;

$\checkmark$ definição do conceito de contrato público socialmente responsável e seu papel no âmbito da proteção e valorização do trabalho humano;

$\checkmark$ a Organização Internacional do Trabalho e sua legitimidade para definir os padrões internacionais mínimos de direitos trabalhistas; 
indicação dos direitos fundamentais no trabalho e os parâmetros e diretrizes válidos para a definição dos padrões mínimos de direitos trabalhistas no plano internacional;

$\checkmark$ a relação direta e intrínseca entre a valorização do trabalho e o princípio da dignidade humana, a estabelecer a perspectiva autêntica do binômio indissociável dignidade-trabalho;

$\checkmark$ a complexidade da economia global contemporânea, a afetar decisivamente o tratamento e a proteção das relações de trabalho;

$\checkmark$ os direitos sociais no trabalho, como dimensão dos direitos humanos, e os especiais desafios para sua efetivação;

$\checkmark$ a insuficiência dos instrumentos normativos tradicionais para assegurar a afirmação da dignidade humana nas relações de trabalho;

$\checkmark$ aspectos concernentes às dificuldades enfrentadas pelas declarações de direitos solenizadas para, de per si, assegurar a eficácia social dos direitos fundamentais;

$\checkmark$ os fatores que vinculam e determinam o comportamento do Poder Público na adoção da dimensão social da contratação pública focada na efetivação dos direitos fundamentais no trabalho;

$\checkmark$ as noções elementares sobre o modo como as empresas são compelidas, no plano internacional, a observar critérios sociais e padrões mínimos de direitos trabalhistas em adjudicações nos contratos públicos e a influência exercida pela cláusula trabalhista como instrumento de concretização e efetivação da proteção dos direitos fundamentais no trabalho;

$\checkmark$ a rejeição social e a reação jurídica em face das organizações que descumprem os direitos fundamentais no trabalho;

$\checkmark$ os elementos definidores e o conteúdo jurídico da cláusula trabalhista nos contratos públicos, com base no estudo e na compreensão das relações existentes entre a dimensão social da contratação pública e a afirmação dos direitos fundamentais no trabalho;

$\checkmark$ o enfrentamento da crise da proteção ao trabalho por meio da reafirmação da vertente dos direitos humanos e da dimensão social dos contratos públicos; 
o verdadeiro papel do Direito como ciência de organização da sociedade e de concretização do sistema de valores almejados, na busca por uma nova dimensão ética global, focada na afirmação dos direitos humanos e na humanização das relações de trabalho, a possibilitar a reconciliação entre desenvolvimento econômico e justiça social, voltada à efetivação das declarações de direitos para a implementação de uma sociedade justa.

Para uma abordagem mais clara e objetiva, que permita a compreensão dos propósitos específicos do trabalho e das questões principais em seu bojo enfrentadas, o texto resultante da pesquisa científica realizada apresenta, no seu núcleo, cinco capítulos principais que se complementam e se inter-relacionam permanentemente.

No primeiro capítulo, é abordada, como tópico central, a dimensão social da contratação pública, ressaltando-se o papel do Estado na afirmação do princípio da dignidade humana, a vinculação dos contratos públicos aos direitos fundamentais, a função social da contratação pública e a atuação da Administração Pública na afirmação dos direitos fundamentais no trabalho. São estudados, demais, os impactos dos sistemas de contratação no setor público. Seguidamente, considerações gerais sobre a contratação pública são tecidas, destacando-se o seu conceito e finalidades essenciais, suas características, os princípios a ela aplicáveis e breve tipologia. Forma, conteúdo e cláusulas essenciais dos contratos públicos são ressaltados. Em profundidade, a conceituação relativa ao denominado contrato público socialmente responsável é estabelecida, considerando o novo papel dos recursos públicos para o desenvolvimento social e a relativização do critério de contratação pelo menor preço. Nesse passo, é contextualizada, com índole introdutória, a relação entre contrato público socialmente responsável e a adoção da cláusula trabalhista. Evidencia-se, de modo inicial, a afirmação dos direitos fundamentais no trabalho por meio dos contratos públicos e a relevante inserção da cláusula trabalhista.

No capítulo segundo, o estudo aborda a determinação dos direitos fundamentais no trabalho no plano internacional, com o apontamento das declarações e dos instrumentos formais pertinentes. Ressalta-se, em referido contexto, o papel da OIT no processo permanente de construção e na afirmação dos direitos fundamentais no trabalho. São discutidos, ainda, os desafios da proteção internacional ao trabalho humano diante da complexidade do mundo moderno, contemplando-se o enfrentamento do dumping social por meio do estabelecimento de standards internacionais de direitos. Em sequencia, são analisadas, como conteúdos definidores principais dos direitos fundamentais no trabalho, a 
Declaração da OIT sobre os Princípios e Direitos Fundamentais no Trabalho e as dimensões específicas de proteção do trabalho decente e do trabalho seguro e saudável, em consonância com as diretrizes da OIT, elucidando-se suas projeções. No que respeita à Declaração de Princípios e Direitos Fundamentais no Trabalho da OIT, são pontuadas as liberdades de associação e de organização sindical e ao reconhecimento efetivo do direito de negociação coletiva, a eliminação de todas as formas de trabalho forçado ou obrigatório, a abolição efetiva do trabalho infantil e a eliminação da discriminação em matéria de emprego e ocupação. Quanto ao direito ao trabalho decente, são exibidos os postulados da OIT a definirem o trabalho produtivo e em condições laborais justas, com a correspondente proteção e aplicação dos princípios e direitos fundamentais no trabalho e normas internacionais do trabalho, a geração de oportunidades de trabalho emprego e renda, o diálogo social e equidade para o desenvolvimento e a proteção social dos trabalhadores, encerrando-se com os preceitos de afirmação do trabalho seguro e saudável. Ademais, a avaliação da necessidade da complementação da atuação da OIT é exposta, tendo em consideração a apreciação sucinta dos mecanismos previstos para a aplicação da Declaração de Princípios e Direitos Fundamentais no Trabalho da OIT e dos postulados do trabalho decente. Os desafios da implementação dos direitos fundamentais no trabalho e da concretização dos direitos sociais são enfrentados nesse momento, representando objetos de atenta análise.

Em seguida, avançando para o terceiro capítulo, é apresentado o conteúdo jurídico da cláusula trabalhista nos contratos públicos e sua decisiva relação com a afirmação dos direitos fundamentais no trabalho. A pesquisa se desenvolve no sentido da compreensão dos aspectos específicos da interseção existente entre os direitos fundamentais no trabalho e o conteúdo jurídico da Convenção ${ }^{\circ} 94$ da OIT, a qual preconiza a adoção da cláusula trabalhista nos contratos firmados por autoridades públicas. É estudada a evolução das cláusulas sociais nos contratos públicos, com indicação de seus antecedentes, fundamentos, assim como sua necessidade e utilidade. $O$ instituto, sua conceituação, relação com a afirmação dos direitos fundamentais no trabalho, natureza jurídica, elementos essenciais, tipos de contrato público aos quais se aplica e efeitos são perquiridos. O exame crítico da Convenção no 94 da OIT e da Recomendação nº 84 da OIT, como fontes formais de direito, é efetuado, propondo-se a atualização e o aperfeiçoamento de suas disposições, em consonância com os novos desafios enfrentados por força das profundas transformações que atingem as relações de trabalho e com a obstinada perseguição da máxima eficácia 
social e jurídica do instituto em exame. O estudo proposto investiga os efeitos da conjugação da dimensão social da contratação pública com o conteúdo jurídico das declarações de direitos humanos no trabalho enquanto conspícuo arcabouço para a construção e efetivação de novo paradigma orientado para a afirmação dos direitos fundamentais trabalhistas. Cláusula trabalhista nos contratos públicos, dignidade humana e a melhoria das condições de trabalho, nessa seção, são apresentadas e relacionadas como fontes geradoras da desejável materialização dos direitos fundamentais no trabalho.

Com ênfase especial, no capítulo quarto, o trabalho se concentra na análise dos aspectos específicos de modelos de cláusulas sociais nos contratos públicos propostos internacionalmente, notadamente no direito europeu e brasileiro, no alvitre de realizar a concretização dos direitos fundamentais no trabalho. O quadro de ratificações da Convenção $n^{\circ} 94$ da OIT é, nesse cenário, exibida. No que concerne ao direito europeu, são observados os critérios sociais de adjudicação nos contratos públicos e analisadas as fontes de direito comunitárias, como as Diretivas 2004/18/CE e 2004/17/CE. No que se refere ao direito brasileiro, o estudo observa a aptidão da contratação pública como instrumento de promoção do desenvolvimento nacional sustentável, com a apreciação dos dispositivos constitucionais aplicáveis, do conteúdo jurídico da lei federal $\mathrm{n}^{\circ} 8.666 / 1993$, a partir das alterações promovidas pela lei federal $n^{\circ} 12.349 / 2010$, além de outras normas correlatas, instruções normativas e outros instrumentos pertinentes. A atuação do Ministério Público do Trabalho, dos Tribunais de Contas e dos sindicatos em relação à temática é destacada nesse ponto. São ressaltadas, ademais, as insuficiências do modelo brasileiro.

No quinto capítulo, o estudo se volta à apreciação da cláusula trabalhista nos contratos públicos como instrumento de afirmação dos direitos fundamentais do trabalho em sua efetiva contribuição para o desenvolvimento sustentável. O trabalho discute a essencialidade da promoção de um modelo verdadeiro de desenvolvimento e de sustentabilidade econômica e social o qual exija a adoção progressiva dos direitos trabalhistas, com a concretização da proteção da dignidade do trabalhador, enaltecendo a cláusula trabalhista nos contratos públicos como instrumento de afirmação de direitos sociais. São tratadas, em associação, as temáticas da função do Direito para a transformação da sociedade e para a afirmação do sistema de valores vigentes e do enfrentamento da crise da proteção ao trabalho por meio da reafirmação da vertente dos direitos humanos e da dimensão social dos contratos públicos. Desse modo, a concretização dos direitos fundamentais no trabalho é apresentada como condição primeira 
na contratação pública focada no valor social do trabalho e na proteção da dignidade do trabalhador como princípios éticos de humanização das relações laborais. Ressalta-se, nesse sentido, a correlação entre cláusula trabalhista nos contratos públicos e justiça social, exibindo-se os aspectos da dimensão social da contratação pública e da necessária harmonização da sustentabilidade social e econômica. Assim sendo, o aperfeiçoamento e a sedimentação dos relevantes postulados de proteção da dignidade humana nas relações laborais prevalecerão.

O encerramento do estudo se dedica à apresentação das considerações finais extraídas da pesquisa levada a efeito, versando, por fim, sobre questões como o processo de desvalorização do trabalho humano e a globalização econômica, sobressaltando os efeitos específicos da relação concludente existente entre a afirmação dos direitos fundamentais, a destinação dos recursos públicos e o desenvolvimento social sustentável. Com denodo especial, evidencia a afirmação da cláusula trabalhista nos contratos públicos como instrumento destinado à concretização dos direitos fundamentais no trabalho, temática a qual, demais, é aclarada e repercutida enquanto argumento indispensável à proteção da dignidade do trabalhador, conquista inalienável da pessoa humana e anseio de toda a comunidade internacional. O resultado final da pesquisa confirma que as intervenções afirmativas do princípio da dignidade humana do trabalhador, além de atualizarem e fortalecerem as bases do Direito do Trabalho constituem meios eficazes de resistência contra as ameaças de retrocesso social. A contratação pública socialmente responsável que valoriza e concretiza os direitos fundamentais no trabalho pode, verdadeiramente, influenciar as atividades econômicas, promovendo a justiça social nas relações de trabalho que encerram. O estudo, enfim, tem a anseio de despertar a sociedade para este autêntico movimento de mudança, observando os parâmetros acadêmicos exigidos para estudos de tal tipo.

O vertente estudo, longe de esgotar os instigantes e profícuos debates que podem ser desencadeados pela apreciação da matéria, almeja tão somente lançar luzes intensas sobre o tema - que está a merecer, fora de dúvida, maior atenção de todos, sejam estudiosos do direito, gestores públicos, legisladores, empresários - e contribuir ao enriquecimento de tão palpitante discussão, a qual se demonstra claramente aberta a novas considerações e aos sempre respeitáveis pontos de vista divergentes que porventura se apresentem. O intuito da pesquisa é, claramente, o de contribuir para o debate com a apresentação ordenada, revestida de estrutura e orientação eminentemente científica, 
enfrentando, de forma crítica e investigativa, específicos aspectos da cláusula trabalhista nos contratos públicos e a afirmação dos direitos fundamentais no trabalho.

\section{Metodologia a ser utilizada}

As bases lógicas da investigação científica do presente trabalho estão sedimentadas principalmente por meio do método dedutivo de abordagem, a partir de pesquisas realizadas na doutrina jurídica, com ênfase no estudo de reconhecidos autores nas disciplinas do Direito do Trabalho, Direito Administrativo, Direitos Humanos, Direito Constitucional, especialmente aqueles que tratam do tema relativo aos direitos fundamentais e sua eficácia, notadamente no que se refere à proteção do trabalho, bem como em decisões judiciais de Tribunais Trabalhistas e do Tribunal de Justiça da União Europeia, em normas da OIT e da União Europeia, cartas constitucionais nacionais, assim como a legislação relacionada à matéria em estudo. Usou-se, além disso, o método indutivo pela constatação de conceitos gerais verificados a partir de fatos específicos e conhecidos. Atendo-se à dogmática jurídica, busca-se, no método analítico-sintético, a extração essencial do conteúdo dos textos e demais documentos compulsados. Explora-se, no aperfeiçoamento da técnica de pesquisa proposta, a investigação firmada na consideração da documentação indireta, com a pesquisa documental de fontes primárias e a pesquisa bibliográfica das fontes secundárias. Livros, artigos de periódicos, consulta ao arcabouço legal, jurisprudência e diplomas internacionais foram constantemente examinados nos meios de mídia impressa e Internet.

\section{Contribuição original para a ciência jurídica brasileira}

A tese proposta, inovadora em termos de sistematização temática, apresenta, de forma original, construção teórica de instrumento de afirmação da dignidade humana no campo jurídico, associado às especificidades do Direito do Trabalho. A pesquisa científica versa sobre tal questão ao propugnar, em seu desenvolvimento, a relação concludente do conteúdo jurídico da cláusula trabalhista nos contratos públicos com a afirmação dos direitos fundamentais no trabalho. 
A partir, essencialmente, do desenvolvimento de pesquisa dogmática, voltada, em prelazia, à identificação, no âmbito jurídico, do tratamento atribuído à temática no plano normativo e doutrinário, o estudo sistemático do "conteúdo jurídico da cláusula trabalhista nos contratos públicos e a afirmação dos direitos fundamentais no trabalho", com rigor na argumentação, profundidade de reflexões e formulação efetiva de avanços na área, proporciona sensíveis contribuições à ciência jurídica brasileira, primando pela originalidade.

O ineditismo da tese se revela, também, na intervenção afirmativa proposta, destinada à concretização e efetivação dos direitos fundamentais no trabalho e de proteção da dignidade humana, bem como na funcionalidade que lhe é inerente como meio de resistência aos efeitos deletérios da precarização da proteção jurídica das condições de trabalho e da dignidade do trabalhador.

A abordagem da dimensão social das contratações do setor público e o papel do Estado na afirmação da dignidade humana, além da formulação de proposta para o aperfeiçoamento do entendimento acerca das disposições da Convenção $\mathrm{n}^{\circ} 94$ da OIT e da Recomendação $\mathrm{n}^{\circ} 84$ da OIT, em correspondente sentido, contribuiem para a temática, dedicada à concretização dos direitos fundamentais no trabalho.

A nova perspectiva do intercâmbio interdisciplinar autêntico que emerge do diálogo entre o Direito Administrativo, o Direito Constitucional e o Direito do Trabalho, sob a regência da teoria dos direitos fundamentais, é demonstrada como necessária conformação à afirmação do princípio da dignidade humana no contexto do estudo proposto.

O resultado final da pesquisa, além de se mostrar inovadora em termos de sistematização do instituto jurídico da cláusula trabalhista nos contratos públicos, evidencia que as intervenções afirmativas do princípio da dignidade humana, demarcada por uma nova visão hermenêutica de materialização dos direitos fundamentais trabalhistas, além de atualizarem e fortalecerem as bases do Direito do Trabalho, constituem meios eficazes de resistência contra as ameaças de retrocesso social. 


\title{
CONSIDERAÇÕES FINAIS
}

Em pleno Século XXI, diante da restrita efetividade das declarações de direitos humanos, a civilização convive, diuturnamente, com graves violações de suas garantias fundamentais. Otavio Pinto e Silva ${ }^{12}$, com percuciência, afirma:

\begin{abstract}
A marginalização afeta uma grande parcela da população mundial, tendo em vista a proliferação da miséria urbana e rural, a falta de condições de saúde, de habitação e de educação, a fome, o desemprego. Esses são alguns dos males que caracterizam a situação de exclusão social pela qual passa grande parte da humanidade e, como não poderia deixar de ser, também o Brasil.
\end{abstract}

A consagração do princípio da dignidade humana nas normas de direito interno, comunitário e internacional não tem promovido, só por si, a necessária realização dos direitos humanos. A proteção da dignidade humana, como núcleo central dos direitos fundamentais, não é concretizada. Trata-se, lamentavelmente, de um cenário inaceitável, em que valores éticos e morais mostram-se claramente afetados. A aparência que decorre do verniz civilizacional, ilustrada por uma democracia que se demonstra mais simbólica do que real, não se reflete na realidade das relações sociais, em que intoleráveis transgressões a direitos fundamentais são flagradas reiteradamente.

O princípio da dignidade humana necessita, como em nenhum outro momento, sair do plano etéreo. Direitos meramente de papel em nada contribuem para o verdadeiro avanço civilizacional por todos ambicionado. Para que a humanidade caminhe celeremente para a realização dos valores sedimentados ao longo de um lento processo de consciência política e jurídica que resultou na construção dos catálogos de direitos fundamentais, impreterível se mostra a efetivação plena dos direitos humanos. A convicção $^{13}$ da

\footnotetext{
${ }^{12}$ SILVA, Otavio Pinto e. A função do Direito do Trabalho no mundo atual. In: CORREIA, Marcus Orione Gonçalves. (Org.). Curso de Direito do Trabalho - Teoria Geral do Direito do Trabalho. V. I. São Paulo: LTr, 2007, p. 142.

${ }^{13}$ Indagado sobre qual seria "a coisa mais importante no mundo", o poeta chileno Pablo Neruda, ao conceder entrevista à escritora brasileira Clarice Lispector em 19 de abril de 1969, respondeu: "Tratar para que o mundo seja digno para todas as vidas humanas, não só para algumas”. Disponível em: http://www.jornalopcao.com.br/posts/opcao-cultural/clarice-lispector-entrevista-pablo-neruda. Acesso em: 14 nov. 2013.
} 
imprescindibilidade da proteção da dignidade humana necessita ser materializada.

A questão da efetividade dos direitos fundamentais afeta com notável magnitude a proteção jurídica dos trabalhadores. A Declaração de Princípios e Direitos Fundamentais no Trabalho da OIT e os postulados do trabalho decente, saudável e seguro, os quais configuram a definição dos padrões mínimos de direitos trabalhistas no âmbito internacional, não têm sido cumpridos nos diferentes países, comprometendo gravemente a tutela deferida à dignidade do trabalhador. Afigura-se alarmante o quadro de déficit de proteção do trabalho digno em todo o mundo.

É preciso assegurar a aplicabilidade e a realização dos direitos trabalhistas fundamentais, combatendo os abjetos casos de trabalho em condições análogas à de escravo, de discriminação de trabalhadores, de cerceamento às liberdades sindicais e negociais, de trabalho infantil, inseguro ou em condições indignas, entre inúmeras outras injustas e execráveis situações vivenciadas no ambiente laboral.

Neste sentido, diante da vinculação à supremacia e à indisponibilidade dos direitos fundamentais como preceptivos essenciais da atividade administrativa no Estado Democrático de Direito, o Poder Público deve exercer sua função interventiva e promocional, induzindo e modelando as condutas sociais. Os governos, fora de dúvida, detém instrumentos poderosos para exigir a concretização dos direitos humanos, principalmente no que concerne aos direitos fundamentais no trabalho e à proteção da dignidade do trabalhador, a qual deve ser a base e o objetivo primordial da atuação estatal.

A implementação do modelo de desenvolvimento sustentável exigido pela sociedade deve abranger, de modo sistêmico, suas dimensões econômica, social e ambiental, vinculando, verdadeiramente, a Administração Pública em sua atuação. O desenvolvimento almejado deve ser socialmente justo, deve ser includente. Embora o desafio da sustentabilidade deva ser enfrentado por toda sociedade, é o Estado, inquestionavelmente, o maior responsável por sua realização. Cada indivíduo tem o direito de obter do Poder Público, ainda que por via indireta, as condições que propiciem a satisfação de suas necessidades econômicas, sociais e ambientais indispensáveis à vida digna, à existência com dignidade.

Os ideais de justiça e de igualdade são primordiais à compreensão do desenvolvimento sustentável, o qual deve contemplar, necessariamente, a dimensão social das contratações públicas e a promoção da tutela nas relações trabalhistas. Sem equidade, 
sem equilíbrio social, não há como garantir desenvolvimento no qual a preservação e a efetividade de direitos são fundamentais para a qualidade da proteção ao trabalho. Definitivamente, não há desenvolvimento sustentável destituído de proteção ao trabalhador.

A contratação pública, como importante instrumento da atuação estatal, está, decididamente, vinculada aos direitos fundamentais, à afirmação do princípio da dignidade humana, à valorização social do trabalho. E, mais do que observá-los, deve efetivá-los, em todos os sentidos. Manifesta, pois, a função essencial dos contratos firmados por autoridades públicas para influenciar a melhoria das condições laborais.

O contrato público, como instrumento jurídico, forçosamente está compelido à agregação dos elementos adequados a assegurar, como preocupação essencial, a implementação de autêntica ação afirmativa vocacionada à concretização dos direitos fundamentais sociais. Sob a ótica da sustentabilidade, obras, bens e serviços são matérias licitáveis a exigir plena e completa subsunção à finalidade legal explicitada.

Defende-se, pois, a cláusula trabalhista nos contratos públicos como instrumento jurídico destinado à afirmação dos direitos fundamentais no trabalho, revestindo-se de plena juridicidade a sua aplicação. Neste sentido, a assegurar e garantir a incorporação dos critérios sociais nas licitações e contratações públicas, apresenta-se o conteúdo normativo da Convenção $n^{\circ} 94$ e da Recomendação n 84 da OIT, da Carta Internacional dos Direitos Humanos, da Declaração da OIT sobre os Princípios e Direitos Fundamentais no Trabalho e das dimensões específicas de proteção do trabalho decente e do trabalho seguro e saudável, dos textos constitucionais e normas de direito interno, comunitário e internacional.

A Convenção no 94 e a Recomendação n ${ }^{\circ} 84$ da OIT representam, propriamente, o reconhecimento internacional da adoção das cláusulas trabalhistas nos contratos públicos enquanto instrumentos jurídicos válidos e necessários para assegurar, aos trabalhadores envolvidos nas contratações públicas, condições laborais justas. De se destacar que, embora tenha sido previsto no âmbito das normas internacionais pela Convenção n ${ }^{\circ}$ 94, da OIT, adotada em 1949, o instituto da cláusula trabalhista nos contratos públicos, o qual preconiza, em seus postulados, o respeito pelas normas fundamentais de proteção ao trabalho humano na execução de contratos firmados por uma autoridade pública, tem sido largamente incompreendido. A pesquisa aperfeiçoada versa sobre tal questão e propugna, em seu desenvolvimento, a relação concludente do conteúdo jurídico da cláusula 
trabalhista nos contratos públicos com a afirmação dos direitos fundamentais no trabalho.

O vertente estudo propõe o fortalecimento da ideia essencial contida na Convenção $\mathrm{n}^{\circ} 94$ da OIT, relacionada à utilização da força vinculante dos contratos públicos como instrumento de efetivação da proteção das condições laborais dos indivíduos, atualizando seu conteúdo para contemplar a concretização dos direitos fundamentais no trabalho, sem os quais se torna inconcebível a afirmação da tutela da dignidade do trabalhador. Da conjugação dos elementos mencionados emerge, com força inelutável, valoroso instituto jurídico.

A cláusula trabalhista nos contratos públicos demanda, para a sua configuração e compreensão, a consideração dos elementos definidores do contrato público socialmente responsável e as dimensões propostas pelos direitos fundamentais no trabalho, admitindo e reconhecendo, com especial ênfase, a centralidade da proteção da dignidade humana do trabalhador como valor ético.

A cláusula trabalhista corresponde ao instrumento que estabelece, por meio da manifestação de vontade imposta em um contrato público, o vínculo ético-jurídico, de índole obrigatória, mantido entre o Estado, a empresa contratada e os trabalhadores envolvidos, destinado a assegurar, de modo concreto, a proteção da dignidade humana do obreiro pela realização dos direitos fundamentais no trabalho nas contratações firmadas por autoridades públicas, resguardando, sempre, a humanização dos vínculos laborais e o comprometimento efetivo com o desenvolvimento e a sustentabilidade da sociedade.

Em consonância com o conteúdo jurídico da cláusula laboral nos contratos públicos, dá-se a afirmação dos direitos fundamentais no trabalho como condição primeira na contratação pública, estabelecida em disposições objetivas, diretas e individualizadas, com a capacidade de exercer seus efeitos em relação às partes que a elaboram e aceitam, sujeitando-se às sanções imediatas que decorrem da sua violação. Atua, assim, como instrumento de ação governamental e de materialização de políticas públicas, possibilitando, sob esta perspectiva, o enfrentamento estrutural idealizado para a construção de um modelo de consolidação permanente e constante dos direitos fundamentais no trabalho.

A força cogente, vinculante, dos contratos, das disposições contratuais, tem a aptidão de subtrair as declarações de direitos subjetivos da generalidade, do plano etéreo e contemplativo, estabelecendo um atrelamento concreto, compulsório, sustentado por 
obrigações individualizadas, exigíveis diretamente, sob pena, em caso de descumprimento do instrumento pactuado, de aplicação direta e imediata de sanções. Tem a capacidade de produzir, portanto, consequências jurídicas efetivas entre as partes contratantes.

A cláusula trabalhista nos contratos públicos suscita a plena efetivação da liberdade de associação e de organização sindical, o reconhecimento efetivo do direito de negociação coletiva, a proscrição de todas as formas de trabalho forçado ou obrigatório, a abolição efetiva do trabalho infantil, a eliminação da discriminação em matéria de emprego e ocupação, a geração de oportunidades de trabalho emprego e renda, o diálogo social e equidade, a proteção social dos trabalhadores, a afirmação do trabalho seguro e saudável. Tutela e promove, assim, um trabalho produtivo e apropriadamente remunerado, executado em condições de liberdade, equidade e segurança, sem discriminação e apto para assegurar uma vida digna aos indivíduos que dele dependam.

Exatamente no atrelamento, na interseção entre o conteúdo das normas de proteção ao trabalho e a força obrigatória e vinculante dos contratos administrativos encontra-se a vocação essencial da cláusula trabalhista nos contratos públicos, a saber, permitir a efetivação dos direitos fundamentais no trabalho.

Os contornos da concepção contemporânea do contrato público socialmente responsável demandam a adoção da cláusula laboral para a afirmação dos direitos fundamentais no trabalho. As características e particularidades do novo regime jurídico em que se inserem os contratos administrativos, exprimem e legitimam a plena pertinência e juridicidade da adoção da cláusula social trabalhista em seu núcleo. A contratação pública socialmente responsável que valoriza e concretiza a proteção da dignidade do trabalhador pode, verdadeiramente, influenciar as atividades econômicas, promovendo a justiça social nas relações de trabalho que encerram ao exigir, com ênfase, a formatação de padrões de emprego e ocupação laboral que respeitam os direitos humanos no trabalho.

Por meio das contratações públicas, as diferentes autoridades governamentais, fazendo uso razoável e proporcional da função interventiva e promocional do Estado na execução de suas finalidades, tornam possível a emergência de um modelo regular de implementação de proteção ao trabalho, conformando o comportamento do setor privado. A incorporação de critérios sociais nas licitações públicas valoriza, com plena legitimidade e legalidade, as organizações que respeitam os direitos fundamentais no trabalho e desestimula a atuação das empresas que se utilizam de trabalho análogo ao de escravo, trabalho infantil, enfim, que desrespeitam a dignidade do trabalhador. A dimensão social 
da contratação por autoridades públicas deve ser consolidada como instrumento autêntico de efetivação dos direitos fundamentais no trabalho.

A admissão da cláusula trabalhista nos contratos públicos corresponde à expressão do intercâmbio disciplinar estabelecido entre Direito do Trabalho, Direito Administrativo e Direito Constitucional, à luz da teoria dos direitos humanos, revelando juridicidade plena como instituto jurídico orientado à efetivação dos direitos fundamentais no trabalho. Evidencia, ainda, à inter-relação existente entre Direito do Trabalho e desenvolvimento sustentável como um novo paradigma.

A adoção da cláusula trabalhista nos contratos públicos com o propósito de promover a afirmação dos direitos fundamentais no trabalho está em absoluta conformidade com a ordem jurídica, com a justiça e com o interesse social. A ação interventiva do Estado para defender a supremacia e indisponibilidade dos direitos humanos, fora de dúvida, reveste-se da mais absoluta licitude e da mais plena validade.

Utilizar o poder de contratação dos governos a fim de promover a materialização dos direitos fundamentais no trabalho, a diminuição das iniquidades, é um meio absolutamente legítimo e eficaz de alcançar a justiça social.

O sistema jurídico brasileiro e o ordenamento normativo europeu convalidam, plenamente, a incorporação da cláusula trabalhista nos contratos públicos com o propósito de promover a afirmação dos direitos fundamentais no trabalho, seja pela adoção do desenvolvimento nacional sustentável como finalidade das licitações, seja pela observância dos critérios sociais de adjudicação nos contratos públicos. Sobretudo, diante do reconhecimento da supremacia e da indisponibilidade dos direitos fundamentais no trabalho a vincular as diferentes manifestações da atividade administrativa. $\mathrm{O}$ estudo do panorama comparativo estabelecido, no tocante ao direito europeu, observa a necessária interação que deve existir entre as condições e exigências econômicas e sociais nos contratos públicos socialmente responsáveis, permitindo, deste modo, a realização do modelo social e do regime jurídico que emana do Tratado de Lisboa, do TFUE, da Carta dos Direitos Fundamentais, das convenções e recomendações da OIT, entre outros diplomas e acordos internacionais aplicáveis, dos parâmetros constitucionais nacionais, das fontes de direito comunitário e de manifestações jurisprudenciais relacionadas.

O desenvolvimento atual do sistema jurídico de contratação pública vigente no Brasil revela que a adoção da cláusula trabalhista destinada à realização dos direitos 
fundamentais está de acordo com as disposições contemporâneas que regem as licitações sustentáveis. Está, outrossim, contemplada na Constituição Federal, na ratificação da Convenção no 94 da OIT, na aprovação da Declaração da OIT sobre os Princípios e Direitos Fundamentais no Trabalho e das dimensões específicas de proteção do trabalho decente e do trabalho seguro e saudável, nas diferentes fontes do direito brasileiro, as quais conferem caráter vinculativo às suas disposições. A partir do contexto apresentado pelo direito nacional posto, consideradas as patentes desigualdades ainda vivenciadas no país, não há dúvida de que os aspectos sociais das contratações públicas sustentáveis assumem intensa relevância. Simplesmente, inexiste desenvolvimento sustentável sem proteção ao trabalhador. A promoção da contratação pública socialmente responsável na realidade nacional demanda, de modo inexorável, a afirmação e concretização dos direitos fundamentais no trabalho.

O estabelecimento de um modelo de intervenção afirmativa, o qual vincula os particulares em colaboração com o Poder Público à realização dos direitos fundamentais laborais, pode representar decisiva política estatal para a promoção da justiça nas relações de trabalho. Em verdade, deixar de adotar a cláusula trabalhista é que enseja gravíssima violação de direitos, inquinando de máculas o contrato público, o ato administrativo pertinente. As decisões da Administração Pública que se mostrem ofensivas aos direitos fundamentais poderão ser invalidadas ante o insuperável vício que revestem. Inexiste fundamento aceitável ou admissível para a postergação da incorporação dos direitos fundamentais sociais. O próprio sistema de proteção internacional impõe a implementação material da proteção social pelas nações. O Poder Público necessita respeitar ${ }^{14}$ o pacto social, cumprindo e fazendo cumprir a constituição e as leis. A proteção insuficiente dos direitos trabalhistas fundamentais, fora de dúvida, trata-se de grave violação constitucional praticada pelo Estado.

Definitivamente, não parece aceitável que recursos públicos financiem a violação de direitos trabalhistas, ou que autoridades administrativas permitam atividades de particulares que desprezam a proteção dos trabalhadores.

A insuficiência, quanto à efetividade, dos instrumentos normativos tradicionais inerentes ao Direito Internacional do Trabalho para assegurar a afirmação da dignidade humana nas relações de trabalho mostra-se nítida. Há real necessidade da existência de institutos que viabilizem os meios de promover intervenção afirmativa destinada à

\footnotetext{
${ }^{14}$ No Brasil, como em outros países, o Poder Público é o maior usuário do sistema judiciário.
} 
concretização e efetivação dos direitos fundamentais no trabalho.

A abordagem apresentada no vertente estudo não tem a pretensão de esgotar o assunto, tampouco almeja se constituir como tratado sobre o tema, o qual revela grande abrangência e incontáveis derivações. A contribuição mais sincera e verdadeira que se busca é a de apresentar, de forma sistematizada, delineamento de instrumento jurídico que permita, em alguma medida, a progressiva efetivação dos direitos fundamentais no trabalho.

Inexiste, realmente, uma resposta única, completa e definitiva para $o$ enfrentamento da reduzida efetividade dos direitos humanos no cenário atual. $\mathrm{O}$ fenômeno do desenvolvimento econômico apresenta complexidade infindável. É preciso questionar permanentemente para evoluir. O conceito de democracia econômica necessita ser disseminado verdadeiramente para contribuir com o ansiado processo de emancipação, voltado ao efetivo progresso social. A desigualdade mostra-se como fator estrutural predominante, cuja mitigação é função precípua dos direitos econômicos e sociais declarados. No campo das relações laborais, a intervenção estrutural focada no lançamento de iniciativas articuladoras de verdadeiras políticas públicas - não individualizadas - de efetivação de direitos mostra-se essencial para o enfrentamento de um novo cenário marcado pelo significativo retrocesso social e pelo aumento da precarização.

O Direito precisa ser visto como instrumento de organização e de transformação social - e não mera forma de declarar direitos subjetivos. Incumbe ao Direito descerrar caminhos para o pleno desenvolvimento do indivíduo em todas as suas dimensões. É imprescindível interferir na distribuição dos recursos, na correlação de interesses, nas consequências econômicas, no acesso à riqueza. As mudanças sociais dependem da construção de instituições. Garantir o respeito aos direitos fundamentais no trabalho, prevenindo os danos aos valiosos bens jurídicos tutelados, corresponde a prover o próprio equilíbrio social e a equidade. Para tanto, a necessidade de avançar na pesquisa e no conhecimento científico dos institutos jurídicos destinados à concretização dos direitos fundamentais no trabalho, seu conteúdo, suas verdadeiras dimensões, as ameaças e consequências que emergem de sua ineficácia. É, pois, inegável a relevância da compreensão plena do conteúdo jurídico da cláusula trabalhista nos contratos públicos e o estudo dos aspectos científicos pertinentes.

O fenômeno da globalização evidenciou realidade inexpugnável, por força da qual os benefícios advindos do mencionado processo não contemplaram os indivíduos de modo 
equitativo. Explicitou, em verdade, que as vantagens advindas do mundialização da economia cingiram-se a pouquíssimos privilegiados. O particular modo como a riqueza criada é distribuída é de fundamental importância para se determinar a construção de uma sociedade justa. Como demonstram e comprovam as diversas declarações e conferências promovidas no âmbito dos diferentes órgãos que integram o sistema da ONU, há uma consciência internacional acerca da necessidade de se implantar um novo modelo de desenvolvimento sustentável no âmbito global.

A valorização extrema dos resultados econômicos, em detrimento dos demais aspectos exigidos pelo desenvolvimento social sustentável, pode levar a sociedade à ruptura e ao caos, verdadeiramente. A crise de valores éticos e morais pode, de fato, gerar retrocessos sociais impensáveis. A ação política, jurídica ${ }^{15}$ e social deve reafirmar o valioso papel desempenhado pelos trabalhadores na conjuntura contemporânea. Revela-se imprescindível reconduzir a dignidade humana à condição de valor supremo e intangível na relação capital-trabalho. Mostra-se prioritário o objetivo de incorporar, definitivamente, os direitos fundamentais sociais ao patrimônio jurídico dos trabalhadores, enquanto garantias irrestringíveis.

As implicações sociais da globalização exigem a afirmação de atitudes efetivas, apropriadas a elidir retrocessos. A dignidade humana é um valor absoluto, insuperável. Ressalta-se, em tal panorama, a necessidade vital, no universo laboral, da afirmação dos direitos fundamentais no trabalho, a serem seguidos e observados universalmente. Todas as nações, elidindo o indesejável e inaceitável retrocesso social, devem almejar a evolução plena na direção dos mais altos padrões de direitos humanos, notadamente no que se refere às garantias trabalhistas, reconhecendo, efetivamente, a importância dos institutos jurídicos destinados a realizar tão relevantes desígnios.

Neste sentido, o estudo da cláusula trabalhista nos contratos públicos demonstra-

\footnotetext{
15 Jorge Luiz Souto Maior, com acuidade, preleciona: "O Direito Social - e esta é a fase atual do Direito, tomada como pressuposto de análise -, afastando qualquer abstração, pressupõe, concretamente, a análise valorativa dos problemas identificados na sociedade capitalista a partir do postulado da necessidade de preservação e elevação da condição humana, tendo como método o olhar das pessoas que se encontram em posição economicamente débil no seio da sociedade, ou de alguma forma fragilizadas, em razão das limitações culturais que se produzem socialmente, embora, quanto aos efeitos, não se limite, exclusivamente, a tais pessoas, visto que a racionalidade provocada se irradia ao direito como um todo, já que o capitalismo é, em última análise, um modelo de sociedade que acaba se introduzindo no próprio inconsciente das pessoas, as quais, desse modo, tendem a reproduzir sua lógica. O Direito Social, a partir desse olhar, objetiva a formulação das coerções eficientes para impor limites necessários às relações capitalistas, visualizando a superação das injustiças sociais geradas." (In: MAIOR, Jorge Luiz Souto. Curso de Direito do Trabalho. Teoria Geral do Direito do Trabalho. Vol. 1. Parte 1. São Paulo: LTr, 2011, p. 56 - grifo nosso).
} 
se inegavelmente atual, considerando-se a expressiva repercussão dos efeitos que colige para a sedimentação dos direitos fundamentais no trabalho, especialmente diante dos desafios e das transformações que se apresentam no novo cenário global. Preconiza-se, dessa forma, o enfrentamento da crise da proteção ao trabalho por meio da reafirmação da vertente dos direitos humanos e da dimensão social dos contratos públicos. O verdadeiro papel do Direito, como ciência de organização da sociedade e de concretização do sistema de valores almejados, emerge na busca por uma nova dimensão ética global. $\mathrm{O}$ foco na afirmação dos direitos humanos, na humanização das relações de trabalho, promove a reconciliação entre desenvolvimento econômico e justiça social, voltada à efetivação das declarações de direitos para a implementação de uma sociedade justa.

Questões advindas da temática do desenvolvimento sustentável devem estar no centro do debate jurídico contemporâneo. O Direito do Trabalho exerce uma função determinante para a sustentabilidade, notadamente no que respeita aos aspectos sociais concernentes. Demanda, pois, instrumentos de efetivação. O combate à pobreza e à desigualdade social deve se situar no foco central das preocupações governamentais a serem consideradas na realização do princípio do desenvolvimento sustentável. Iniciativas voltadas à tutela dos direitos dos trabalhadores e à extensão da proteção social são meios sustentáveis de reduzir as iniquidades.

A efetivação dos padrões internacionais de proteção ao trabalhador apresenta-se, assim, como conditio sine qua non para o desenvolvimento sustentável. Considerando a influente interação e a interdependência existentes entre Direito do Trabalho e desenvolvimento sustentável, é possível conceber as condições para o surgimento de um novo parâmetro para a ação governamental. A concretização dos direitos fundamentais no trabalho deve, portanto, ser objeto central da atuação estatal. No âmbito das licitações e contratações do Poder Público, a cláusula trabalhista nos contratos públicos manifesta-se como expressão real de tal desiderato.

Não há qualquer dúvida de que a contratação pública socialmente responsável pode representar uma transformação autêntica, com o potencial de demonstrar consistente crescimento, provocando impactos no contexto normativo, no âmbito dos comportamentos dos governantes, dos administradores públicos, das corporações. A contratação pública, ao exigir, como condição objetiva, o cumprimento pleno dos direitos fundamentais no trabalho, estabelece uma influente simbiose, que tem o desejável potencial de otimizar a efetividade. A cláusula laboral, ademais, obriga um olhar constante, permanente, dos 
administradores públicos para a realidade dos trabalhadores e para a essencialidade de sua proteção. O respeito ao fundamento central da dignidade humana por meio da tutela do trabalho e de seu valor social deve ser compreendido como legítimo imperativo ético, como princípio basilar e essencial, a influenciar a compreensão do Direito Administrativo e a ação das autoridades públicas nas contratações administrativas.

A proposta da aplicação do conteúdo jurídico da cláusula trabalhista nos contratos públicos apresenta-se, a um só tempo, como corpo e em espírito. Corpo, na medida em que deve constar expressamente nos instrumentos contratuais que envolvam o Poder Público, ou recursos públicos, cumprindo seu desígnio de cláusula contratual, com força vinculante concreta, objetiva, individualizada. Em espírito, na medida em que suas aspirações, como autêntico critério social nas contratações públicas, norteie os atos da Administração Pública, destinando-se à concretização dos direitos fundamentais no trabalho, à afirmação dos preceptivos de supremacia e indisponibilidade dos direitos humanos, imprescindíveis ao desenvolvimento sustentável. Como uma autêntica tomada de consciência, como um paradigma norteador da postura da autoridade administrativa. Sem proteção efetiva, concreta, palpável, ao trabalhador, não existe desenvolvimento sustentável.

Para assegurar, verdadeiramente, a proteção ao trabalho, a cláusula trabalhista deve ser considerada como elemento central das contratações públicas e do desenvolvimento sustentável. A adoção do instituto jurídico da cláusula trabalhista nos contratos públicos deve representar a consolidação da dimensão social da contratação por autoridades públicas como instrumento autêntico de efetivação dos direitos fundamentais no trabalho no sistema capitalista. Deve expressar a repulsa do Direito às contratações públicas ou ao uso de recursos públicos que financiem violações aos padrões internacionais de proteção do trabalhador, evidenciando a supremacia e a indisponibilidade dos direitos fundamentais como preceptivos essenciais da atividade administrativa no Estado Democrático de Direito.

O trabalho, em consonância com a premissa já exposta, é o meio fundamental dado à pessoa para efetivar e sublimar sua existência com dignidade. Sua tutela, em decorrência, assume diferenciado relevo e notória importância. A imperiosa necessidade da proteção do trabalhador e a legítima demanda social pela concretização dos direitos fundamentais no trabalho constituem o embasamento maior para o desenvolvimento de instrumentos capazes de ensejar a materialização de tão relevantes valores. Nesse sentido, a contribuição determinante do instituto da cláusula trabalhista nos contratos públicos, o 
qual deve ser promovido, exigido e fortalecido para estabelecer a relação direta e intrínseca entre a valorização do trabalho e o princípio da dignidade humana, na perspectiva do indissociável binômio dignidade-trabalho.

O trabalho é, inquestionavelmente, um dos pilares de sustentação da atividade produtiva e dos sistemas econômicos. Fragmentá-lo ou precarizá-lo significaria a desestruturação de toda a sociedade, ocasionando irreparáveis malefícios. Não resta dúvida de que a proteção ao trabalho, enquanto alicerce fundamental, deve se inserir, com primazia, nas dimensões políticas, econômicas e sociais do desenvolvimento sustentável e da responsabilidade de governos e empresas, conformando um novo padrão ético para a vida em sociedade. 


\section{REFERÊNCIAS BIBLIOGRÁFICAS}

ABRANTES, José João. Contrato de Trabalho e Direitos Fundamentais. Coimbra: Coimbra, 2005.

AGRA, Walber de Moura. Curso de Direito Constitucional. Rio de Janeiro: Forense, 2012.

ALEXANDRINO, Marcelo; PAULO, Vicente. Direito Administrativo Descomplicado. 20. ed. São Paulo: Método, 2012.

ALEXY, Robert. Teoria de los derechos fundamentales. Madri: Centro de Estudios Políticos Y Constitucionales, 2002.

ALMEIDA, Renato Rua de (Coord.). Direitos Fundamentais Aplicados ao Direito do Trabalho. São Paulo: Ltr, 2010.

. (Coord.). Direitos Fundamentais Aplicados ao Direito do Trabalho - II. São Paulo: Ltr, 2012.

ALVES, Marcos César Amador. Relação de Trabalho Responsável. São Paulo: LTr, 2011.

AMADO, Frederico. Direito Ambiental Esquematizado. 3. ed. São Paulo: Método, 2012.

ANDRADE, José Carlos Vieira de. Os Direitos Fundamentais na Constituição Portuguesa. Coimbra: Almedina, 1987.

ARAGÃO, Selma Regina. Direitos Humanos na ordem mundial. Rio de Janeiro: Forense, 2000.

ARENDT, Hannah. A condição humana. Rio de Janeiro: Forense-Universitária, 1987.

Entre o passado e o futuro. São Paulo: Perspectiva, 1992.

ARRUDA JÚNIOR, Edmundo Lima de (org.). Globalização, neoliberalismo e o mundo do trabalho. Curitiba: Edibej, 1998.

ASHLEY, Patrícia Almeida. Ética e responsabilidade social nos negócios. São Paulo: Saraiva, 2005.

BAGOLINI, Luigi. O Trabalho na Democracia. Brasília: UnB, 1981, p. 36.

BARRoso, Luís Roberto. A Dignidade da Pessoa Humana no Direito Constitucional Contemporâneo: Natureza Jurídica, Conteúdos Mínimos e Critérios de Aplicação. Versão provisória para debate público. Mimeografado, dezembro de 2010. Disponível em: http://www.osconstitucionalistas.com.br/wp-content/uploads/2010/12/LRBarroso-A dignidade-da-pessoa-humana-no-Direito-Constitucional-contemporaneo.pdf. Acesso em: 
04 nov. 2013.

Neoconstitucionalismo, e constitucionalização do Direito: o triunfo tardio do direito constitucional no Brasil. In: QUARESMA, Regina; OLIVEIRA, Maria Lúcia de Paula; OLIVEIRA, Farlei Martins Riccio de (Org.). Neoconstitucionalismo. Rio de Janeiro: Forense, 2009.

O Estado Contemporâneo, os direitos fundamentais e a redefinição da supremacia do interesse público. In: SARMENTO, Daniel (Org.). Interesses públicos versus interesses privados. Rio de Janeiro: Lumen Juris, 2005, p. IX - X.

BASTOS, Filipe Brito. A escolha de critérios ambientais de adjudicação de contratos públicos reflexões de Direito Administrativo nacional e europeu. Disponível em: http://www.icjp.pt/sites/default/files/papers/escolhacriteriosambientaisadjudicacaocp.pdf. Acesso em: 19 ago. 2013.

BELTRAN, Ari Possidonio. Direito do Trabalho e direitos fundamentais. São Paulo: LTr, 2002.

Impactos da integração econômica no Direito do Trabalho - globalização e direitos sociais. São Paulo: LTr, 1998.

BETIOL, Luciana Stocco. et. al. Compra Sustentável: a força do consumo público e empresarial para uma economia verde e inclusiva. São Paulo: FGV - Programa Gestão Pública e Cidadania, 2012, p. 144.

BIDERMAN, Rachel; BETIOL, Luciana Stocco; MACEDO, Laura Silvia Valente de; MONZONI, Mario; MAZON, Rubens (Orgs.). Guia de Compras Públicas Sustentáveis: Uso do poder de compra do governo para a promoção do desenvolvimento sustentável. 2. ed. São Paulo: Centro de Estudos em Sustentabilidade da Escola de Administração de Empresas de São Paulo da Fundação Getulio Vargas (GVces), 2008.

BLANCHET, Jeanne D’Arc Anne Marie Lucie. A função social da empresa, a liberdade econômica e o bem comum. Curitiba: Genesis, 2004.

BOBBIO, Norberto. A era dos direitos. Rio de Janeiro: Campus, 1996.

Da estrutura e da função: novos estudos de Teoria do Direito. São Paulo: Manole, 2007.

Teoria da norma jurídica. São Paulo: Edipro, 2001.

1994.

Teoria do Ordenamento Jurídico. 4. ed. Brasília: Universidade de Brasília,

BOCORNY, Leonardo Raupp. A valorização do Trabalho Humano no Estado Democrático de Direito. Porto Alegre: Sergio Antonio Fabris Editor, 2003.

BONAVIDES, Paulo. Curso de Direito Constitucional. 7. ed. São Paulo: Malheiros, 1998. 
Do Estado Liberal ao Estado Social. 7. ed. São Paulo: Malheiros, 2004.

BRAYN, Alessandra S. Almeida. Trabalho decente: uma avaliação das possibilidades de aplicação do conceito. Dissertação (Mestrado em Economia Política) - Faculdade de Economia, Pontifícia Universidade Católica de São Paulo, 2006.

BRITTO, Carlos Ayres. O Regime Constitucional dos Tribunais de Contas. Revista Interesse Público - $\mathrm{n}^{\circ}$ 13. Porto Alegre: Notadez, 2002.

BRITO FILHO, José Claudio Monteiro de. Trabalho decente: análise jurídica da exploração, trabalho forçado e outras formas de trabalho indigno. São Paulo: LTr, 2004.

CÂMARA, Alexandre Freitas. Lições de Direito Processual Civil. Vol. L. 9. ed. Rio de Janeiro: Lúmen Júris, 2003.

CAMARgos, Ana Amélia Mascarenhas. Direito do Trabalho no Terceiro Setor. São Paulo: Saraiva, 2008.

CANOTILHO, José Joaquim Gomes. Constituição dirigente e vinculação do legislador: contributo para a compreensão das normas constitucionais programáticas. Coimbra: Coimbra Editora, 1994.

1999.

Direito Constitucional e Teoria da Constituição. 3. ed. Coimbra: Almedina,

. Direito Constitucional. 6. ed. Coimbra: Almedina, 1995.

. Estudos sobre Direitos Fundamentais. Coimbra: Coimbra, 2004.

; MOREIRA, Vital. Fundamentos da Constituição. Coimbra: Coimbra, 1991.

CAPRA, Fritjof. O ponto de mutação. 25. ed. São Paulo: Cultrix, 1999.

CARBONARI, Paulo César. A construção dos Direitos Humanos. Revista Eletrônica Portas, p. 5-14, jun.2007. Disponível em: http://www.acicate.com.br/portas/artigo1.pdf. Acesso em: 31 mai. 2012.

CASSESE, Antonio. I diritti umani nel mondo contemporaneo. 5. ed. Roma: Laterza, 1999.

CASTELO, Jorge Pinheiro. O Direito Material e Processual do Trabalho e a PósModernidade - A CLT, o CDC e as repercussões do novo Código Civil. São Paulo: Ltr, 2003.

CAVAlCANTE FILHO, João Trindade. Teoria geral dos direitos fundamentais. Disponível em:

http://www.stf.jus.br/repositorio/cms/portalTvJustica/portalTvJusticaNoticia/anexo/Joao_T rindadade_Teoria_Geral_dos_direitos_fundamentais.pdf . Acesso em: 19 set. 2013.

CHERNI, Judith A. Economic Growth versus the Environment: The Politics of Wealth, 
Health and Air Pollution. UK: Palgrave, 2002.

COMISSÃO EUROPEIA. Compra social: guia para ter em conta os aspectos sociais nos concursos públicos. Luxemburgo: Serviços das Publicações da União Europeia, 2011.

COMPARATO, Fábio Konder. A afirmação histórica dos Direitos Humanos. 2. ed. São Paulo: Saraiva, 2001.

Ética, Direito, Moral e Religião no Mundo Moderno. São Paulo: Companhia das Letras, 2010.

Fundamento dos Direitos Humanos. Disponível em:

http://www.dhnet.org.br/direitos/militantes/comparato/comparatola.html. Acesso em:

30 out. 2013

CORREIA, Marcus Orione Gonçalves. CORREIA, Marcus Orione Gonçalves. (Org.). Curso de Direito do Trabalho - Teoria Geral do Direito do Trabalho. São Paulo: Ltr, 2007, v. I.

O contrato individual do trabalho no contexto neoliberal: uma análise crítica. Revista LTr, v. 67, n. 4, maio, p. 422-429. São Paulo: LTr, 2003.

CRETELLA JÚNIOR, José. Das licitações públicas - comentários à Lei Federal n. 8.666, de 21 de junho de 1993. 18. ed. Rio de Janeiro: Forense, 2008.

CRIVELLI, Ericson. A OIT e o futuro das normas internacionais do trabalho na era da globalização. Tese (Doutorado em Direito Internacional). Faculdade de Direito, Universidade de São Paulo, 2004.

CRUZ, Claudia Ferreira. Os direitos fundamentais dos trabalhadores e a carta sociolaboral do Mercosul. São Paulo: LTr, 2006.

DALLARI, Dalmo de Abreu. Direitos Humanos e cidadania. São Paulo: Moderna, 1998.

DANTAS, Ivo. Direito constitucional comparado: introdução, teoria e metodologia. Rio de Janeiro: Renovar, 2000.

DELGADO, Gabriela Neves. Direito fundamental ao trabalho digno. São Paulo: LTr, 2006.

Opção pelo direito do trabalho. Jornal Estado de Minas. Belo Horizonte: Edição do dia 29.09.2006, p.15.

DELGADO, Maurício Godinho. Capitalismo, Trabalho e Emprego: entre o paradigma da destruição e os caminhos de reconstrução. São Paulo: LTr, 2006.

Curso de Direito do Trabalho. 7. ed. São Paulo: LTr, 2007.

Direitos fundamentais na relação de trabalho. Revista de Direitos e Garantias Fundamentais - nº 2, 2007. Vitória: FDV, 2007. 
DEON, Rodrigo. Os impactos sociais diante do ressurgimento das ideias liberais, e a dignidade da pessoa humana, como limite à flexibilização do Direito do Trabalho. DireitoNet, São Paulo, 04.02.2004. Disponível em:

http://www.direitonet.com.br/artigos/x/14/52/1452/. Acesso em: 06 abr. 2009.

DESCARTES, René. Discurso do método. São Paulo: Martins Fontes, 1999.

DIMOULIS, Dimitri. Manual de Introdução ao Estudo do Direito. São Paulo: RT, 2003.

DI PIETRO, Maria Sylvia Zanella. Direito administrativo. 22. ed. São Paulo: Atlas, 2009.

EIDE, Asbjorn. Obstacles and Goals to be Pursued. In: EIDE, Asbjorn; KRAUSE, Catarina; ROSAS, Allan. Economic, Social and Cultural Rights. Dordrecht, Boston e Londres: Martinus Nijhoff Publishers, 1995

ESTORNINHO, Maria João. Direito Europeu dos Contratos Públicos (Um Olhar Português). Coimbra: Almedina, 2006.

Green Public Procurement - Por uma contratação Pública Sustentável. Disponível em: http://www.icjp.pt/sites/default/files/media/texto_profa_mje.pdf. Acesso em: 16 ago. 2013.

FACHIN, Melina Girardi. Direito fundamental ao desenvolvimento - uma possível ressignificação entre a Constituição Brasileira e o sistema internacional de proteção dos direitos humanos. In: PIOVESAN, Flávia; SOARES, Inês Virgínia Prado (Coords.). Direito ao desenvolvimento. Belo Horizonte: Fórum, 2010, p. 179-198.

FALAVIGNA, Maria Clara Osunna Diaz. Os princípios gerais do Direito e os standards jurídicos no Código Civil. Tese (Doutorado em Direito Civil). Faculdade de Direito, Universidade de São Paulo, 2007.

FARIA, José Eduardo. Direitos Humanos, Direitos Sociais e Justiça. São Paulo: Malheiros, 1994.

FARIAS, Edílsom Pereira de. Colisão de direitos. Porto Alegre: Fabris, 1996.

Liberdade de Expressão e Comunicação: teoria e proteção constitucional. São Paulo: Revista dos Tribunais, 2004.

FERRARI, Irany; NASCIMENTO, Amauri Mascaro e MARTINS FILHO e Ives Gandra. História do trabalho, do Direito do Trabalho e da Justiça do Trabalho. São Paulo: LTr, 1998.

FERRAZ JÚNIOR, Tercio Sampaio. Função social da dogmática jurídica. São Paulo: RT, 1980. 1, 1995, p. 10.

Interesse Público. Revista do Ministério Público do Trabalho da $2^{\mathbf{a}}$ Região, $\mathrm{n}$. 
Atlas, 2003.

Introdução ao estudo do direito: técnica, decisão, dominação. 4. ed. São Paulo:

FERREIRA, Daniel; MACIEL FILHO, Fernando Paulo da Silva. A funcionalização das licitações e dos contratos administrativos com vistas à promoção do desenvolvimento nacional sustentável. Disponível em:

http://www.publicadireito.com.br/artigos/?cod=0cbed40c0d920b94. Acesso em: 08.11.2013.

FERREIRA FILHO, Manoel Gonçalves. Comentários à Constituição brasileira de 1988. Vol. I. São Paulo: Saraiva, 1990.

. Curso de Direito Constitucional. 26. ed. São Paulo: Saraiva, 1999.

FILHO, José Soares. A Crise do Direito do Trabalho em Face da Globalização. Revista LTR, v. 66. São Paulo: LTr, 2002.

FURTADO, C. O Nordeste: reflexões sobre uma política alternativa de desenvolvimento. Revista de Economia Política, São Paulo, v. 4, n. 3, p. 5-14, jul.-set. 1984. (Centro de Economia Política). Disponível em: http://www.rep.org.br/pdf/15-1.pdf. Acesso em:

05 set. 2013.

1983.

Teoria e Política do Desenvolvimento Econômico. 8. ed. São Paulo: Nacional,

FERREIRA, Daniel; GODOY, Maria Ivone. A promoção do desenvolvimento nacional sustentável e a certidão negativa de débitos trabalhistas (CNDT). Revista Jurídica Unicuritiba. V. 2. no 29 (2012). Curitiba: Unicuritiba, 2012, p. 341. Disponível em: http://revista.unicuritiba.edu.br/index.php/RevJur/article/view/527/411. Acesso em: 25 set. 2013.

FRIEDMANN, Georges. Tratado de Sociologia do Trabalho. São Paulo: Cultrix, 1973.

FRIEDMAN, Thomas. O mundo é plano: Uma breve história do século XXI. Rio de Janeiro: Objetiva, 2005.

GALANTINO, Luisa. Diritto sindacale. Turim: G.Giappichelli, 1996.

GALINDO, Bruno. Direitos Fundamentais - análise de sua concretização constitucional. Curitiba: Juruá, 2003.

GARCIA, Emerson (Coord.). A efetividade dos direitos sociais. Rio de Janeiro: Lumen Juris, 2004.

GARCIA, Gustavo Filipe Barbosa. Curso de Direito Processual do Trabalho. Rio de Janeiro: Forense, 2012.

Direitos fundamentais e relação de emprego. São Paulo: Método, 2008. 
GIDDENS, Anthony. A terceira via: reflexões sobre o impasse político atual e o futuro da social-democracia. Rio de Janeiro: Record, 2000.

GOUVÊA, Carlos Portugal. Direitos Sociais contra os Pobres. Disponível em: http://www.law.yale.edu/documents/pdf/sela/SELA11_Gouvea_CV_Port_20110514.pdf Acesso em: 31 mai. 2012.

GRAU, Eros Roberto. A ordem econômica na Constituição de 1988: interpretação e crítica. 4. ed. São Paulo: Malheiros, 1998.

GUIMARÃES, Ricardo Pereira de Freitas. Manual de direito individual do trabalho. São Paulo: Revista dos Tribunais, 2013.

GÜNTHER, Klaus. Teoria da Argumentação no Direito e na Moral: Justificação e Aplicação. Traduzido por Claudio Molz. São Paulo: Landy, 2004.

HABERMAS, Jürgen. O discurso filosófico da modernidade. Lisboa: Publicações Dom Quixote, 2000.

HART, Herbert L. A. O conceito de Direito. Lisboa: Fundação Calouste Gulbenkian, 1986.

HELOANI, Roberto. Gestão e organização no capitalismo globalizado. São Paulo: Atlas, 2003.

HERKENHOFF, João Batista. Curso de Direitos Humanos. V. I. São Paulo: Acadêmica, 1994.

HESSE, Konrad. A força normativa da Constituição. Porto Alegre: Sérgio Fabris, 1991.

HOBSBAWM, Eric. O novo século. São Paulo: Companhia das Letras, 2000.

HOLANDA, Aurélio Buarque de. Novo dicionário Aurélio da Língua Portuguesa. 7. ed. São Paulo: Positivo, 2008.

JAVILLIER, Jean-Claude. Manual de Direito do Trabalho. São Paulo: LTr, 1988.

Pragmatismo e inovação no Direito Internacional do Trabalho. In: Revista Synthesis. Resumo do artigo publicado em Revista Internacional del Trabajo, vol. 113/94. São Paulo: Tribunal Regional do Trabalho da 2. ${ }^{a}$ Região, nº 22/96.

JOÃO, Paulo Sérgio. Participação nos lucros ou resultados das empresas. São Paulo: Dialética, 1998.

JUAREZ, Freitas. O controle dos atos administrativos e os princípios fundamentais. São Paulo: Malheiros, 1997.

JUSTEN FILHO, Marçal. Comentários à lei de licitações e contratos administrativos. 13. ed. São Paulo: Dialética, 2009. 
. Curso de direito administrativo. São Paulo: Saraiva, 2005.

. Desenvolvimento nacional sustentado: contratações administrativas e o regime introduzido pela Lei 12.349/10. Disponível em:

http://www.justen.com.br//informativo.php?\&informativo=50\&artigo $=528 \& \mathrm{l}=\mathrm{pt} . \quad$ Acesso em: 31 mai. 2012.

KANT, Immanuel. A paz perpétua e outros opúsculos. Lisboa: Edições 70, 1995.

Crítica da razão pura. São Paulo: Abril, 1993.

. Fundamentação da metafísica dos costumes e outros escritos. São Paulo: Martin Claret, 2004,

KRÜGER, Kai; NIELSEN, Ruth; BRUUN, Niklas. European public contracts in a labour law perspective. Copenhagen: DJOF Publishing, 1998.

KÜNG, Hans. SCHMIDT, Helmut. Introdução para a Declaração do Parlamento das Religiões do Mundo: uma ética mundial e responsabilidades globais. São Paulo: Loyola, 2001 .

LAFER, Celso. A reconstrução dos Direitos Humanos. São Paulo: Companhia das Letras, 1991.

LOUREIRO, Luiz Guilherme. Contratos. 3. ed. São Paulo: Método, 2008.

MAIOR, Jorge Luiz Souto. O Direito do Trabalho como instrumento de justiça. São Paulo: LTr, 2000.

Curso de Direito do Trabalho. Teoria Geral do Direito do Trabalho. Vol. 1. Parte 1. São Paulo: LTr, 2011.

MALLET, Estevão. Direito, trabalho e processo em transformação. São Paulo, LTr, 2005.

Temas de direito do trabalho. São Paulo, LTr, 1998.

MANRICH Nelson, A administração pública do trabalho em face da autonomia privada coletiva. In: MALLET, Estevão e ROBORTELLA, Luiz Carlos Amorim (Coords.) Direito e processo do trabalho: estudos em homenagem ao Prof. Octavio Bueno Magano. São Paulo: LTr, 1996.

Inspeção do trabalho. São Paulo: LTr, 1991.

MANUS, Pedro Paulo Teixeira. Direito do Trabalho. 6. ed. São Paulo: Atlas, 2001.

O Direito do Trabalho na nova Constituição. São Paulo: Atlas, 1989.

MARCIAL, Danielle, ROBERT, Cínthia, SÉGUIN, Elida. O direito do desenvolvimento. Rio de Janeiro: Lumen Juris, 2000, p. 48. 
MARQUES NETO, Floriano Peixoto de Azevedo. A concessão como instituto do direito administrativo. Tese (apresentada ao concurso para provimento de cargo de Professor Titular). Faculdade de Direito, Universidade de São Paulo, 2013.

Bens públicos função social e exploração econômica o regime jurídico das utilidades públicas. Belo Horizonte: Fórum, 2009.

(Org.); ARAGÃO, Alexandre Santos de (Org.). Direito Administrativo e seus novos paradigmas. Belo Horizonte: Fórum, 2008.

Do contrato administrativo à administração contratual. Revista do advogado, ano 29, no 107, dez., p. 74-82. São Paulo: AASP, 2009.

MARTINS, Adalberto. Manual didático de Direito do Trabalho. 3. ed. São Paulo: Malheiros, 2009.

MARTINS, Ives Gandra e REZEK, Francisco (Coords.). Constituição Federal - avanços, contribuições e modificações no processo democrático brasileiro. São Paulo: Revista dos Tribunais, 2008.

MARTINS, Sérgio Pinto. Direito do Trabalho. São Paulo: Atlas, 1995.

1996.

Práticas discriminatórias contra a mulher e outros estudos. São Paulo: LTr,

MARTINS FILHO, Ives Gandra da Silva. O ordenamento jurídico brasileiro. Revista Jurídica Virtual, Brasília, v. 1, n. 3, jul. 1999. Disponível em:

http://www.planalto.gov.br/ccivil_03/revista/Rev_03/ordenamento\%20jur\%20brasil.htm.

Acesso em: 16 set. 2013.

MATTIOLI, Maria Cristina. As Políticas Públicas para Promover e Implementar os Direitos Fundamentais no Trabalho e a Integração Econômica Internacional. Disponível em: http://www.usp.br/prolam/cadernos2003/2003b/06m_c_mattioli.pdf. Acesso em:

31 mai. 2012.

Responsabilidade Social e Legal das Empresas Transnacionais. Brasília: Revista do Tribunal Superior do Trabalho-TST, Dezembro, 2003.

MCCRUDDEN, Christopher. Buying Social Justice: Equality, Government Procurement \& Legal Change. New York: Oxford University Press, 2007.

MEDAUAR, Odete. Direito Administrativo Moderno. 6. ed. São Paulo: Revista dos Tribunais, 2002.

MEIRELLES, Hely Lopes. Direito administrativo brasileiro. 26. ed. São Paulo: Malheiros, 2001.

Licitação e contrato administrativo. 25. ed. São Paulo: Malheiros, 2010. 
MELO, Osvaldo Ferreira de. Fundamentos da Política Jurídica. Porto Alegre: Fabris Editor, 1994.

MELlO, Celso Antonio Bandeira de. Curso de direito administrativo. 5. ed. São Paulo: Malheiros, 1994.

MELlo, Celso Duvivier de Albuquerque. Curso de Direito Internacional Público volume I. 9. ed. São Paulo: Renovar, 1992.

O $\S 2^{\circ}$ do art. $5^{\circ}$ da Constituição Federal. In: TORRES, Ricardo Lobo (org.).

Teoria dos Direitos Fundamentais. 2. ed. Rio de Janeiro: 2010, p. 1-29.

MENDES, Renato Geraldo. O regime jurídico da contratação pública. Curitiba: Zênite, 2008.

MIRANDA, Jorge. Manual de Direito Constitucional. Coimbra: Coimbra, 1994.

SILVA, Marco Antonio Marques da. (Coords.). Tratado Luso-brasileiro da dignidade humana. São Paulo: Quartier Latin, 2008.

MIRÀNDOLA, Pico della. A dignidade do homem. Traduzido por Luiz Feracini. São Paulo: Escala, 1999, p. 42.

MONREAL, Eduardo Novoa. O Direito como obstáculo à transformação social. Porto Alegre: Sergio Antonio Fabris Editor, 1988.

MONTORO, André Franco. Introdução à ciência do direito. 20. ed. São Paulo: Revista dos Tribunais, 1991.

MORAES, Alexandre de. Direito Constitucional. 14. ed. São Paulo: Atlas, 2003.

Direitos Humanos Fundamentais: teoria geral. 4. ed. São Paulo: Atlas, 2002.

MOREIRA NETO. Diogo de Figueiredo. Curso de Direito Administrativo. Rio de Janeiro: Forense, 2002, p. 524.

MORETTO, Amilton José. Políticas de emprego e sua contribuição à redução da informalidade e discriminação no mercado de trabalho brasileiro: a experiência recente. Brasília: Organização Internacional do Trabalho - Escritório no Brasil, 2010.

NALINI, José Renato; CARLINI, Angélica. Direitos Humanos e formação jurídica. Rio de Janeiro: Forense, 2010.

NASCIMENTO, Amauri Mascaro. Comentários às leis trabalhistas. São Paulo: LTr, 1991.

Curso de Direito do Trabalho. 19. ed. São Paulo: Saraiva, 2004.

Direito do Trabalho na Constituição de 1988. São Paulo: Saraiva, 1991. 
Direito Sindical. São Paulo: Saraiva, 1989.

Iniciação ao Direito do Trabalho. 31. ed. São Paulo: LTr, 2005.

NETTO, Luísa Cristina Pinto e; BITENCOURT NETO, Erico (Coord.). Direito administrativo e direitos fundamentais. Belo Horizonte: Fórum, 2012.

NOVELINO, Marcelo. Direito Constitucional. 7. ed. São Paulo: Método, 2012.

NUNES, Luiz Antônio Rizzato. O princípio da dignidade da pessoa humana: doutrina e jurisprudência. São Paulo: Saraiva, 2002.

OLEA, Manoel Alonso. Da escravidão ao contrato de trabalho. Curitiba: Juruá, 1990.

OLIVEIRA, Gustavo Justino de. Administração pública democrática e efetivação de direitos fundamentais. Disponível em:

http://www.justinodeoliveira.com.br/wpcontent/uploads/2011/11/14_AdmPubDemocratica .pdf . Acesso em 31 mai. 2012.

Direito ao desenvolvimento na Constituição Brasileira de 1988. Disponível em:http://www.justinodeoliveira.com.br/wpcontent/uploads/2011/10/26_Direitoaodesenvol vimento._Gustavo_Justino_mar_08.pdf. Acesso em: 14 out. 2013.

OLIVEIRA, Marcos Antonio de. SA 8000 - O modelo ISO 9000 aplicado à responsabilidade social. Rio de Janeiro: Qualitymark, 2003.

OLIVEIRA, Isabel Silva Dutra de. Alternativas para implementação da avaliação ambiental estratégica no Brasil. (Tese de Doutorado). São Carlos: Universidade de São Paulo, 2008, p. 191.

ORGANIZAÇÃO DAS NAÇÕES UNIDAS. Full and productive employment and decent work. Nova York: Departament of economic and social affairs, 2006.

World economic situation and prospects 2008. Nova York: Departament of economic and social affairs, 2008.

ORGANIZAÇÃO INTERNACIONAL DO TRABALHO. A fair globalization - creating opportunities for all. Genebra: World commission on the social dimension of globalization, 2004.

2006.

Changing patterns in the world of work. Genebra: International labour office,

Convenio (núm. 94) y recomendacion (núm. 84) sobre las cláusulas de trabajo (contratos celebrados por lãs autoridades públicas), 1949. Guía práctica. Genebra: OIT, 2008.

Decent work. Genebra: International labour office, 1999.

Decent working time - new trends, new issues. Genebra: International labour 
office, 2006.

Declaración de la OIT relativa a los principios y derechos fundamentales en el trabajo. 24 maio 2004. Disponível em:

http://www.ilo.org/declaration/thedeclaration/textdeclaration/lang--es/index.htm. Acesso em: 31 mai. 2012.

- Emprego, desenvolvimento humano e trabalho decente: a experiência brasileira recente. Brasília: CEPAL, 2008.

Governance, International Law \& Corporate Social Responsibility. Genebra: International labour office, 2008.

. Labour clauses in public contracts. Genebra: International labour office, 2008.

Toolkit for mainstreaming employment and decent work. Genebra: International labour office, 2007.

Perspectives on decent work. Genebra: International labour office, 2000.

ORGANIZAÇÃO PARA A COOPERAÇÃO E DESENVOLVIMENTO ECONÔMICO. DAC Guidelines and Reference Series. Harmonising Donor Practices for Effective Aid Delivery Volume 3: Strengthening Procurement Practices in Developing Countries, Paris, 2005. Disponível em: http://www.oecd.org/dataoecd/12/14/34336126.pdf. Acesso em: 31 mai. 2012.

The size of government procurement markets, Paris, 2002. Disponível em: http://www.oecd.org/dataoecd/34/14/1845927.pdf . Acesso em: 31 mai. 2012.

ORTIZ DIAS, José. El horizonte de las administraciones públicas en el cambio de siglo: algunas consideraciones de cara al año 2000. In: SOSA WAGNER, Francisco (Coord.) El derecho administrativo en el umbral del siglo XXI: homenage al Profesor Dr. D. Ramón Martín Mateo. Valencia: Tirant lo Blanch, 2000. t. 1, p. 63-117.

PASTORE, José. Normas trabalhistas e comércio internacional: o debate sobre a cláusula social. Brasília: Mimeo, 1997.

PATRUNO, M. Manuale di Diritto della Comunità Europea. 2. ed. Roma: CxT, 1996.

PEIXINHO, Manoel Messias; FERRARO, Suzani Andrade. Direito ao desenvolvimento como direito fundamental. XVI Congresso Nacional do CONPEDI. Belo Horizonte: Fundação Boiteux, 2007. Disponível em:

http://www.conpedi.org.br/manaus/arquivos/anais/bh/manoel_messias_peixinho.pdf.

Acesso em: 08 nov. 2013.

PENNA, Carlos Gabaglia. O estado do planeta. A sociedade de consumo e a degradação ambiental. Rio de Janeiro: Record, 1999.

PETTER, Josué Lafayete. Princípios Constitucionais da Ordem Econômica: o significado e o alcance do art. 170 da Constituição Federal. São Paulo: Revista dos 
Tribunais, 2005.

PEREIRA, Luiz C. Bresser. Desenvolvimento e crise no Brasil. 7. ed. Brasília: Brasiliense, 1977.

PEREZ LUÑO, Antonio Enrique. Derechos Humanos, estado de derecho y Constitución. 3. ed. Madri: Teccnos, 1990.

Los Derechos fundamentales. Madri: Teccnos, 1993.

PIMENTA, José Roberto Freire (coord.) et. al. Direito do Trabalho: Evolução, crise e perspectivas. São Paulo: LTr, 2004.

PIOVESAN, Flávia. Direitos Humanos e o Direito Constitucional Internacional. 8. ed. São Paulo: Saraiva, 2007.

Direitos Humanos e o trabalho: principiologia dos Direitos Humanos aplicada ao Direito do Trabalho. São Paulo: Revista do Advogado - AASP, n. 97, p. 73, 2008.

Direitos Humanos, globalização econômica e integração regional: desafios do direito constitucional internacional. São Paulo: Max Limonad, 2002.

Direitos Humanos Globais, Justiça Internacional e o Brasil. Disponível em: http://www.escolamp.org.br/arquivos/15_07.pdf. Acesso em: 16 jul. 2008.

A Incorporação, a Hierarquia e o Impacto dos Tratados Internacionais de Proteção dos Direitos Humanos no Direito Brasileiro. In: GOMES, Luiz Flávio e PIOVESAN, Flávia (Coords.). O Sistema Interamericano de Proteção dos Direitos Humanos e o Direito Brasileiro. São Paulo: Revista dos Tribunais, 2000, p. 156.

Temas de Direitos Humanos. São Paulo: Max Limonad, 1998.

PEREIRA, Potyara A. Necessidades Humanas. 2. ed. São Paulo: Cortez, 2002.

RAMALHO, Maria do Rosário Palma. Da autonomia dogmática do Direito do Trabalho. Coimbra: Livraria Almedina, 2000.

REALE, Miguel. Filosofia do Direito. 17. ed. São Paulo: Saraiva, 1996.

Lições Preliminares de Direito. São Paulo: Saraiva, 1998.

RÍBAR, Geórgia. Os princípios constitucionais da dignidade da pessoa humana, da igualdade e o princípio da não discriminação na proteção contra a discriminação na relação de emprego. Revista LTr, nº 9. São Paulo: LTr, 2006.

RIFKIN, Jeremy. O fim dos empregos. São Paulo: Makron books, 1995.

ROBORTELLA, Luiz Carlos Amorim. O moderno Direito do Trabalho. São Paulo: LTr, 1994. 
ROCCELlA, Massimo. Diritto del Lavoro della Comunità Europea. Pádua: CEDAM, 1995.

RODRIGUES, Marta Maria Assumpção. Políticas públicas. São Paulo: Publifolha, 2010.

RODRIGUEZ, Américo Plá. Princípios de Direito do Trabalho. São Paulo: LTr, 1993.

ROMITA, Arion Sayão. Globalização da economia e Direito do Trabalho. São Paulo: LTr, 1997.

SACHS, Ignacy. Desenvolvimento: includente, sustentável, sustentado. Rio de Janeiro: Garamond, 2004.

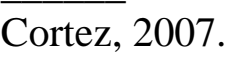

Rumo à ecossocioeconomia: teoria e prática do desenvolvimento. São Paulo:

SALOMÃO FILHO, Calixto. Direito como instrumento de transformação social e econômica. Revista de Direito Público da Economia, Belo Horizonte, a. 1, n. 1, p. 15-44, jan./mar. 2003, p. 33.

SAMPAIO, Ricardo Alexandre. A Lei $\mathbf{n}^{0}$ 12.349/10 e a indução de políticas públicas para promover o desenvolvimento nacional sustentável. Disponível em:

http://jus.com.br/artigos/18687/a-nova-lei-no-8-666-93\#ixzz2i1fsbX2s. Acesso em:

17 out. 2013.

SANTOS, Boaventura de Sousa. O caos da ordem. Jornal Folha de São Paulo. Seção Opinião. São Paulo: Edição do dia 16.08.2011, p. 3.

Pela mão de Alice. O social e o político na pós-modernidade. 9. ed, revista e aumentada. Coimbra: Almedina, 2013.

SANTOS, Enoque Ribeiro dos. Internacionalização dos Direitos Humanos trabalhistas: o advento da dimensão objetiva e subjetiva dos direitos fundamentais. Revista LTr, vol. 72, $n^{\circ}$ 03, mar., p. 277. São Paulo: LTr, 2008.

SANTOS, Mauro Sérgio dos. Curso de Direito Administrativo. Rio de Janeiro: Forense, 2012.

SANTOS, Murillo Giordan; BARKI, Teresa Villac Pinheiro (Coords.). Licitações e contratações públicas sustentáveis. Belo Horizonte: Fórum, 2011.

SANTOS, Ronaldo Lima dos. Sindicatos e ações coletivas: acesso à Justiça, jurisdição coletiva e tutela dos interesses difusos, coletivos e individuais homogêneos. 2. ed. São Paulo: Editora LTr, 2008. v. 1.

SANTOS NETO, João Antunes dos. O impacto dos direitos humanos fundamentais no direito administrativo. São Paulo: Fórum, 2012, preâmbulo.

SARLET, Ingo Wolfgang. A eficácia dos direitos fundamentais. 4. ed. Porto Alegre: Livraria do Advogado, 2004. 
. A lei fundamental da Alemanha nos seus 60 anos e o Direito Constitucional Brasileiro: algumas aproximações. Revista Direitos Fundamentais \& Justiça: Porto Alegre, v.3, n.7, p.89-95, jun. 2009.

Constituição, direitos fundamentais e direito privado. Porto Alegre: Livraria do Advogado, 2001.

Dignidade da pessoa humana e direitos fundamentais. 6. ed. Porto Alegre: Livraria do Advogado, 2008.

Direitos Humanos e Democracia. Rio de Janeiro: Forense, 2007.

SARMENTO, Daniel. Direitos fundamentais e relações privadas. 2. ed. Rio de Janeiro: Lumen Juris, 2006.

SCHMITT, Carl. Teoría de la constitución. Madri: Alianza, 1996.

SCHULTEN, Thorsten; ALSOS, Kristin; BURGESS, Pete; PEDERSEN, Klaus. Pay and other social clauses in european public procurement - An overview on regulation and practices with a focus on Denmark, Germany, Norway, Switzerland and the United Kingdom. Düsseldorf: WSI - Hans Böckler Stifung - EPSU, 2012.

SEM, Amartya. Desenvolvimento como liberdade. São Paulo: Companhia das Letras, 2000, p. 19-20.

SILVA, Homero Batista Mateus da. Curso de direito do trabalho aplicado, Volume 1, Parte Geral. Rio de Janeiro: Campus, 2008.

SILVA, José Afonso da. A dignidade da pessoa humana como valor supremo da democracia. Ética, democracia e justiça: Livro de teses da XV Conferência Nacional da OAB. OAB: Foz do Iguaçu, 1994.

. Curso de Direito Constitucional Positivo. São Paulo: Malheiros, 1993.

Princípios do Processo e Formação das Leis no Direito Constitucional. São Paulo: Revista dos Tribunais, 1964.

SILVA, Luis Virgilio Afonso da. A constitucionalização do direito: os direitos fundamentais nas relações entre os particulares. São Paulo: Malheiros, 2005.

SILVA, Otavio Pinto e. A contratação coletiva como fonte do direito do trabalho. São Paulo: LTr, 1998.

Subordinação, autonomia e parassubordinação. São Paulo: LTr, 2004.

A função do Direito do Trabalho no mundo atual. In: CORREIA, Marcus Orione Gonçalves. (Org.). Curso de Direito do Trabalho - Teoria Geral do Direito do Trabalho. São Paulo: Ltr, 2007, v. I, p. 142-155. 
SILVA NETO, Manoel Jorge. Direito Constitucional e Econômico. São Paulo: LTr, 2001.

SILVA, de Plácido e. Vocabulário Jurídico. 29. ed. Rio de Janeiro: Forense, 2012.

SILVESTRE, Rita Maria; NASCIMENTO, Amauri Mascaro. Os novos paradigmas do Direito do Trabalho. São Paulo: Saraiva, 2001.

SOMAVÍA, Juan. Reducir el déficit de trabajo decente: un desafío global. Disponível em:

http://www.ilo.org/public/spanish/standards/relm/ilc/ilc89/pdf/rep-i-a.pdf. Acesso em:

07 nov. 2013

SOUZA, Celina. Políticas Públicas: uma revisão da literatura. 2006. Revista Sociologias, ano 8, $\mathrm{n}^{\mathrm{o}}$ 16, jul/dez 2006. Porto Alegre: Universidade Federal do Rio Grande do Sul Instituto de Filosofia e Ciências Humanas - Programa de Pós-Graduação em Sociologia, 2006, p. 24.

SOUZA NETO, Cláudio Pereira e SARMENTO, Daniel (orgs.) et al. A constitucionalização do direito. Rio de Janeiro: Lumen Juris, 2007.

SUNDFELD, Carlos Ari. Fundamentos de Direito Público. São Paulo: Malheiros, 1992.

SÜSSEKIND, Arnaldo Lopes. Convenções da OIT. 2. ed. São Paulo: LTr, 1998.

Direito Internacional do Trabalho. São Paulo: LTr, 2000.

TAVARES, André Ramos. Curso de Direito Constitucional. São Paulo: Saraiva, 2003.

Direito Constitucional Econômico. São Paulo: Método, 2003.

TRINDADE, Antônio Augusto Cançado. A proteção internacional dos Direitos Humanos e o Brasil: as primeiras cinco décadas. Brasília: Universidade de Brasília, 2000.

Tratado de Direito Internacional dos Direitos Humanos. Porto Alegre: Sergio Antonio Fabris Editor, 1997.

TRUBEK, David. Economic, Social and Cultural Rights in the Third World: Human Rights Law and Human Needs Programs. In: MERON, Theodor (E.). Human Rights in International Law: Legal and Policy Issues. Oxford: Claredon Press, 1984.

VIANNA, Segadas, MARALHÃO, Délio e SÜSSEKIND, Arnaldo Lopes. Instituições de Direito do Trabalho. Rio de Janeiro: Freitas Bastos, 2003.

VIEIRA, Maria Margareth Garcia. A Globalização e as Relações de Trabalho. Curitiba: Juruá, 2000.

VIEIRA, Oscar Vilhena. Direitos Fundamentais - uma leitura da jurisprudência do STF. São Paulo: Malheiros, 2006. 
WALD, Arnoldo. O Direito de Parceria e a nova Lei de Concessões. São Paulo: Revista dos Tribunais, 1996. 